\title{
Development, Diversity, and Function of Dendritic Cells in Mouse and Human
}

\author{
David A. Anderson III, ${ }^{1}$ Kenneth M. Murphy, ${ }^{1,2}$ and Carlos G. Briseño ${ }^{1}$ \\ ${ }^{1}$ Department of Pathology and Immunology, Washington University in St. Louis, School of Medicine, St. Louis, \\ Missouri 63110 \\ ${ }^{2}$ Howard Hughes Medical Institute, Washington University in St. Louis, School of Medicine, St. Louis, \\ Missouri 63110 \\ Correspondence: kmurphy@pathology.wustl.edu
}

\begin{abstract}
The study of murine dendritic cell (DC) development has been integral to the identification of specialized DC subsets that have unique requirements for their form and function. Advances in the field have also provided a framework for the identification of human DC counterparts, which appear to have conserved mechanisms of development and function. Multiple transcription factors are expressed in unique combinations that direct the development of classical DCs (cDCs), which include two major subsets known as CDC1s and cDC2s, and plasmacytoid DCs (pDCs). pDCs are potent producers of type I interferons and thus these cells are implicated in immune responses that depend on this cytokine. Mouse models deficient in the cDC1 lineage have revealed their importance in directing immune responses to intracellular bacteria, viruses, and cancer through the cross-presentation of cell-associated antigen. Models of transcription factor deficiency have been used to identify subsets of CDC2 that are required for Thelper (Th)2 and Th17 responses to certain pathogens; however, no single factor is known to be absolutely required for the development of the complete CDC2 lineage. In this review, we will discuss the current state of knowledge of mouse and human DC development and function and highlight areas in the field that remain unresolved.
\end{abstract}

\section{DEVELOPMENT AND FUNCTION OF MURINE AND HUMAN DENDRITIC CELL SUBSETS}

C lassical dendritic cells (cDCs) and plasmacytoid DCs (pDCs) make up the two major subsets of DCs that exist in mice and humans. Among cDCs in mice, two major lineages have been identified and are referred to as $\mathrm{CDC} 1 \mathrm{~s}$ and cDC2s (Guilliams et al. 2014). cDC1s express high levels of IRF8 and are dependent on Irf8 (Schiavoni et al. 2002; Aliberti et al. 2003), Batf3
(Hildner et al. 2008; Edelson et al. 2010), Id2 (Hacker et al. 2003; Kusunoki et al. 2003), Nfil3 (Kashiwada et al. 2011), and Bcl6 for their development (Ohtsuka et al. 2011; Watchmaker et al. 2014). cDC2s express IRF4 and also IRF8 but at levels lower than $\mathrm{CDC} 1$ cells, and can be subdivided into at least two functionally distinct subsets that either require the transcription factors Notch2 or KLF4 (Satpathy et al. 2013; Schlitzer et al. 2013; Tussiwand et al. 2015). pDCs also express high levels of IRF8, similar to levels expressed by $\mathrm{cDC} 1 \mathrm{~s}$, but depend on the

Editors: Warren J. Leonard and Robert D. Schreiber

Additional Perspectives on Cytokines available at www.cshperspectives.org

Copyright (C) 2018 Cold Spring Harbor Laboratory Press; all rights reserved; doi: 10.1101/cshperspect.a028613

Cite this article as Cold Spring Harb Perspect Biol 2018;10:a028613 
D.A. Anderson et al.

transcription factor E2-2 for their development (Cisse et al. 2008). cDCs and pDCs develop from a common progenitor in the bone marrow (BM), known as the macrophage DC progenitor (MDP), which has both DC and macrophage potential (Fogg et al. 2006; Auffray et al. 2009). Restriction to the DC lineage occurs downstream of the MDP at a stage defined as the common DC progenitor (CDP) (Naik et al. 2007; Onai et al. 2013), which can give rise to both pDCs and cDCs. Cells in the gate that defined the CDP were characterized by expression of intermediate levels of c-Kit and by expression of both Flt3 (CD135 $)$ and M-CSFR $\left(\mathrm{CD} 115^{+}\right)$, differing from the MDP that expresses c-Kit at high levels. The CDP is negative for expression of CD11c and MHC class II molecules. Subsequent studies identified populations within BM that appeared to be a common progenitor of cDCs, termed pre-cDCs, that were first identified in the spleen (Naik et al. 2006) and later independently identified in the BM (Liu et al. 2009). A common marker of both pre-cDCs was the expression of CD11c, and in the BM these cells were defined as expressing Flt3.

Identification of Distinct Committed Progenitors of cDC1 and cDC2 in Murine Bone Marrow

The identification of progenitors with potential for only one type of cDC initially relied on the use of a reporter for the gene $Z b t b 46$, which had been previously identified as a marker for cDCs (Meredith et al. 2012; Satpathy et al. 2012a). One study found that the expression of the $Z b t b 46^{\text {gfp }}$ reporter allele by immature cells in the BM was associated with commitment of these cells to the cDC lineage and the exclusion of pDC potential (Satpathy et al. 2012a). However, that study did not examine the various subpopulations of cells expressing Zbtb46. Subsequently, it was recognized that Zbtb46 was expressed heterogeneously in BM cells, by populations of cells that expressed intermediate levels of c-Kit, similar to expression levels in the CDP, but also by cells that lacked c-Kit expression. The majority of the $\mathrm{c}-\mathrm{Kit}^{\mathrm{int}}$ population expressing $\mathrm{Zbtb} 46^{\mathrm{gfp}}$ expressed Flt3 $\left(\mathrm{CD} 135^{+}\right)$but did not express M-
CSFR $\left(\mathrm{CD} 115^{-}\right)$. However, it was discovered that these two populations represented a divergence in the potential for $\mathrm{CDC}$ subsets, with the $\mathrm{C}^{-\mathrm{Kit}^{\mathrm{int}}}$ population being committed to the $\mathrm{cDC} 1$ lineage and the $\mathrm{c}-\mathrm{Kit}^{-/ \mathrm{lo}}$ population being committed to the cDC2 lineage. These populations were referred to as pre-cDC1 and precDC2 cells, respectively (Grajales-Reyes et al. 2015). An intriguing finding of this study was that the pre-cDC1 cell could develop even in BM of $B a t f 3^{-/-}$mice, indicating that specification of the pre-cDC1 did not require BATF3. It appeared that the action of BATF3 was rather late in the developmental process and acted to maintain the expression of the Irf8 gene by interaction with IRF8 at an enhancer site. In a contemporaneous study, single-cell RNA-Seq on pre-DCs, which were defined as $\mathrm{Lin}^{-} \mathrm{CD} 11 \mathrm{c}^{+} \mathrm{MHCII}^{-}$ $\mathrm{CD}_{135}{ }^{+} \mathrm{CD} 172 \mathrm{a}^{-}$, revealed heterogeneity in expression of SiglecH and Ly6C that could be used to identify pre-cDC1 and pre-cDC2 progenitors. Pre-cDC1 cells were identified as $\mathrm{SiglecH}^{-}$ Ly6C $^{-}$and pre-cDC2s were SiglecH $\mathrm{H}^{-} \mathrm{Ly}_{6 \mathrm{C}}^{+}$ (Table 1) (Schlitzer et al. 2015). The SiglecH ${ }^{+}$ fraction of the pre-DC was found to give rise to all DC subsets, including $\mathrm{pDCs}$ and $\mathrm{cDCs}$, independent of Ly6C expression. The expression of Ly6C indicated the potential for $\mathrm{CDC} 2$, but the levels of c-Kit or M-CSRF were unspecified. It is not clear at this time whether the populations described in these two studies represent the same stages of $\mathrm{CDC} 1$ and $\mathrm{CDC} 2$ specification, and this will await additional analysis. These two studies also differ in the interpretation of whether a clonally identifiable pre-cDC exists. Schlitzer et al. (2015) suggested the existence of a true pre-cDC stage lacking pDC potential but retaining the ability to generate both types of cDCs. Grajales-Reyes et al. (2015) showed that $\mathrm{cKit}^{\text {int }} \mathrm{Zbtb} 46^{\mathrm{gfp}+}$ cells that arise from the CDP but lack functional Batf3 can divert into the cDC2, but not pDC lineage. Thus, conceivably, a natural rate of failure in commitment specification of pre-cDC1 could explain some cDC2 development, but no homogeneous population lacking $\mathrm{pDC}$ potential and retaining both $\mathrm{CDC} 1$ and cDC2 potential has emerged. Notably, the previously defined pre-cDC in the BM retained substantial pDC potential (Liu et al. 2009) and 
Murine and Human Dendritic Cells

Table 1. Markers of lineage committed murine pre-DCs

\begin{tabular}{|c|c|c|c|c|}
\hline $\begin{array}{l}\text { Surface } \\
\text { marker }\end{array}$ & $\begin{array}{c}\text { Pre-cDCl } \\
\text { (Grajales-Reyes et al. } \\
\text { 2015) }\end{array}$ & $\begin{array}{c}\text { Pre-cDCl } \\
\text { (Schlitzer et al. } \\
\text { 2015) }\end{array}$ & $\begin{array}{c}\text { Pre-cDC2 } \\
\text { (Grajales-Reyes et al. } \\
\text { 2015) }\end{array}$ & $\begin{array}{c}\text { Pre-cDC2 } \\
\text { (Schlitzer et al } \\
\text { 2015) }\end{array}$ \\
\hline MHCII & int & - & - & - \\
\hline Zbtb46 & + & $?$ & + & $?$ \\
\hline CDllc & + & + & + & + \\
\hline CD24 & + & + & - & - \\
\hline CD115 & - & $?$ & + & $?$ \\
\hline CD117 & int & $?$ & - & $?$ \\
\hline CD135 & + & + & + & + \\
\hline CD172a & int & - & int & - \\
\hline Ly6C & $?$ & - & $?$ & + \\
\hline SiglecH & - & - & $?$ & - \\
\hline
\end{tabular}

Summary of surface marker expression used by two independent groups to identify murine preclassical dendritic cells (cDCs) committed to $\mathrm{CDCl}$ or $\mathrm{cDC} 2$ lineages. Question marks indicate that the expression for a marker was not reported for or used to define the population in the study.

was heterogeneous for c-Kit and MHCII expression. Previously defined pre-cDCs and recently defined pre-cDC1 and pre-cDC2 emerge from the $\mathrm{BM}$, can be identified in the blood, and seed peripheral tissues where they are thought to proliferate, although the extent of local proliferation has been difficult to quantify in vivo (Liu and Nussenzweig 2010; Grajales-Reyes et al. 2015). There are a number of remaining unanswered questions regarding the development of these progenitors, particularly with respect to the mechanisms of transcriptional control. Below we will discuss the extension of these findings to human DCs, but first we describe several additional aspects of development and function in murine DCs.

\section{cDC1 Development and Function}

Single deficiencies in Irf8, Batf3, Nffil3, Id2, and $B c l 6$ are all associated with the loss of $\mathrm{cDC} 1 \mathrm{~s}$ in lymphoid and nonlymphoid tissues (Schiavoni et al. 2002; Aliberti et al. 2003; Hacker et al. 2003; Kusunoki et al. 2003; Hildner et al. 2008; Edelson et al. 2010; Kashiwada et al. 2011; Ohtsuka et al. 2011; Watchmaker et al. 2014). The mechanisms underlying the requirement for these factors are still a matter of active investigation. Recently, BATF3 was found to function in cDC1 development by acting in the maintenance of the high levels of IRF8 that are already expressed in the CDP. This function of BATF3 is exerted through its interaction with IRF8 at a specific enhancer site in the Irf8 gene locus that mediates transcriptional autoactivation. This enhancer appears to become activated during specification of the pre-cDC1 cell upon the induction of Batf3 expression at the final stages of $\mathrm{CDC} 1$ specification in the CDP. Deficiency in Batf3 did not cause a loss of the identifiable precDC1 cells in the BM, indicating that BATF3 is not required for the initial specification process per se but results in the subsequent decay of IRF8 protein levels and diversion of the specified pre-cDC1 cells into the $\mathrm{CDC} 2$ lineage (GrajalesReyes et al. 2015). This result explains the loss $\mathrm{cDC1}$ s in all lymphoid and nonlymphoid tissues in Batf $3^{-/-}$mice under homeostatic conditions. This also explains why cDC1s in Batf $3^{-1-}$ mice can be restored under other conditions, such as during infection or treatment with interleukin (IL)-12 through the induction of Batf that can compensate for Batf3 deficiency and rescue cDC1 development (Tussiwand et al. 2012). In Itgax-Cre $\operatorname{Irf} 8^{\mathrm{fl} / \mathrm{fl}}$ mice, in which Irf8 is deleted downstream of the CDP, $\mathrm{CDC} 1 \mathrm{~s}$ exhibit reduced survival in peripheral tissues, demonstrating that Irf8 is also required during the terminal stages of $\mathrm{cDCl}$ development (Sichien et al. 2016).

With the knowledge that $\mathrm{CDC1}$ development is Irf8-dependent, observations that either 
D.A. Anderson et al.

deficiency in Irf8 or DC-dependent IL-12 production results in susceptibility to Toxoplasma gondii shed light on the specialized functions of cDC1 cells (Scharton-Kersten et al. 1997; Liu et al. 2006). It was first demonstrated that these defects were intrinsic to $\mathrm{cDC} 1 \mathrm{~s}$ through the generation of $\mathrm{Batf3}^{-/-}:$Il12p40 $40^{-/-}$mixed BM chimeras, in which IL-12 production is only deficient in cDC1s (Mashayekhi et al. 2011). It was also revealed by using Batf $3^{-1-}$ mice that $\mathrm{CDC1}$ s are required for cross-presentation of exogenous antigen to CD8 T cells, which in turn is required for antiviral and antitumor responses (Hildner et al. 2008). While normally conferring protection to pathogens, cDC1s can also confer susceptibility in certain cases, such as in the setting of blood-borne infection by Listeria monocytogenes. In this particular setting, $\mathrm{CDC} 1 \mathrm{~s}$ act as the primary cellular target of infection that leads to the spread of the pathogen into the lymphoid areas of the spleen, where massive cellular loss occurs as a result (Edelson et al. 2011a). Surprisingly, mice lacking BATF3, and thus lacking cDC1s, were remarkably resistant to intravenous infection by L. monocytogenes (Edelson et al. 2011a). Although the adaptive function of cDC1s is largely considered to be restricted to immune responses mediated by CD $8 \mathrm{~T}$ cells and $\mathrm{T}$ helper (Th) 1 cells, Batf $3^{-1-}$ mice have enhanced Th2 responses to helminth infection, a phenomenon attributed to loss of constitutive expression of IL-12 by DC1s (Everts et al. 2016).

\section{cDC2 Development and Function}

Although several transcription factors are implicated in regulating $\mathrm{cDC} 2$ development, there is, to our knowledge, no mutant mouse model in which cDC2 development is selectively ablated. This is in contrast to several single transcription factors whose deletion can ablate cDC1 development. RelB was the first transcription factor to be implicated in the development of cDC2s (Burkly et al. 1995; Weih et al. 1995). Germline deletion of Relb in mice causes a multifaceted phenotype that includes splenomegaly, extramedullary hematopoiesis, multiorgan inflammation, myeloid hyperplasia, and disturbed de- velopment of thymic and splenic cDCs (Burkly et al. 1995; Weih et al. 1995). Initial studies performed to determine the cell-intrinsic requirements for RelB in DC development claimed that cDCs did not develop in wild-type (WT) chimeras reconstituted with Relb $^{-/-} \mathrm{BM}$; however, little to no evidence was ever provided in these studies to support such a statement (Burkly et al. 1995; DeKoning et al. 1997; Gerloni et al. 1998a,b). Subsequent independent analysis showed that thymic $\mathrm{CD} 8 \alpha^{+} \mathrm{cDC} 1$ s develop normally in Relb $^{-1-}$ WT chimeras, but suggested that there was a cell-intrinsic requirement for RelB in the development of CD8 $\alpha^{-} \operatorname{Dec} 205^{-}$ cDC2s (Wu et al. 1998). Another report confirmed reduced cDC numbers in Relb $^{-1-}$ mice but did not establish a cell-intrinsic requirement for their development or function (Kobayashi et al. 2003). Very recently, our analysis concluded that the majority of $\mathrm{cDCs}$ show no cellintrinsic requirement for RelB for their development (Briseno et al. 2017) with one exception. There was a cell-intrinsic requirement for RelB only in the development of the $\mathrm{CD}^{+} \mathrm{Esam}^{+}$ cDC2 subset of the spleen (Briseno et al. 2017), a subset that is also dependent on Notch2 signaling (Satpathy et al. 2013) and lymphotoxin $\beta$ (LT- $\beta$ ) receptor signaling (Kabashima et al. 2005). This subset of cDC2 cells appears to represent a terminal maturational stage of cDC2 cells (Satpathy et al. 2013) that develops in response to Notch ligands expressed in specific lymphoid tissue niches (Fasnacht et al. 2014). This similarity between the phenotypes caused by deficiency in Relb and LT- $\beta$ receptor might suggest that RelB could act downstream of this receptor in the final maturation of $\mathrm{cDC} 2$ progenitors in such lymphoid niches. However, the majority of $\mathrm{cDCs}$ in lymph nodes and peripheral organs showed no cell-autonomous requirement for RelB in their development. There was, however, a role for RebB in nonhematopoietic tissues that regulated the myeloid compartment. Specifically, Relb $^{-1-}$ recipient chimeras reconstituted with WT BM showed a similarly abnormal myelopoiesis to that observed in germline $\mathrm{Relb}^{-1-}$ mice, indicating that the initially reported abnormality of myeloid cells in $\mathrm{Relb}^{-1-}$ mice was a result of loss of 
RelB in nonhematopoietic, radio-resistant cells. Although Relb $^{-1-}$ cDCs are able to activate T cells against cell-associated antigens (Briseno et al. 2017), a role for RelB in other cDC functions has not been excluded, although these are unknown at present. A novel floxed allele for conditional deletion of Relb should facilitate such studies (De Silva et al. 2016).

The functional specialization of $\mathrm{CDC} 2 \mathrm{sub}$ sets has been revealed using models of transcription factor deletion. Itgax-Cre-mediated deletion of Notch 2 and the signaling partner, $R b p j$, results in the loss of $c D C 2 s$ in the spleen

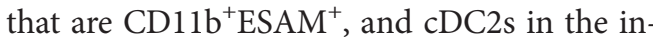
testinal lamina propia and mesenteric lymph nodes that are $\mathrm{CD} 103^{+} \mathrm{CD} 11 \mathrm{~b}^{+}$(Satpathy et al. 2013). Loss of this subset is associated with susceptibility to Citrobacter infection. Mortality at the early time point of day 10 after infection in Notch $2^{\mathrm{l} / \mathrm{fl}}$ Itgax-Cre mice suggested a role for the Notch2-dependent cDC2 subset in innate defense, in addition to its expected role in adaptive immunity. Using mixed chimeras of Itgax-Cre Notch $2^{\mathrm{fl} / \mathrm{fl}}$ and Il23a $a^{-/-}$BM, it was found that IL-23 production by the Notch2-dependent CDC2 subset is required during Citrobacter infection (Satpathy et al. 2013). IL-23 is known to activate ILC3 cells for production of IL-22, a cytokine that is required to maintain the barrier function of intestinal epithelial cells (Zheng et al. 2008; Sonnenberg and Artis 2015). Reduced numbers of Th17 cells has also been observed in models where the development or function of cDC2s is impaired. Itgax-Cre Irf4 $4^{\mathrm{fl} / \mathrm{fl}}$ mice show a defect in the production of Th17polarizing cytokines on immunization and reduced Th17 populations at homeostasis (Persson et al. 2013; Schlitzer et al. 2013). A specific deficiency in transforming growth factor $\beta$ (TGF- $\beta$ ) or IL-6 in CD11c-expressing cells is also sufficient to reduce Th17 polarization following infection with Streptococcus pyogenes (Persson et al. 2013; Schlitzer et al. 2013; Linehan et al. 2015). A specific requirement for cytokine production by $\mathrm{cDC} 2 \mathrm{~s}$, rather than other CD11c-expressing subsets, in Th17 polarization has not been established.

At steady state, expression of $\mathrm{Klf} 4$ is required for the development or function of a subset of migratory cDC2 cells that are $\mathrm{CD} 11 \mathrm{~b}^{-} \mathrm{CD} 24^{-}$ in the skin-draining lymph node and $\mathrm{CD} 24^{+}$ $\mathrm{CD} 172 \mathrm{a}^{+} \mathrm{Mgl} 2^{+}$in the lung. A loss of these cells in Itgax-Cre $\mathrm{Klf}^{\mathrm{fl} / \mathrm{fl}}$ mice correlates with enhanced susceptibility to helminth infection and enhanced lung inflammation during house dust mite challenge (Tussiwand et al. 2015). These results are consistent with previous studies that used an Mgl2-DTR and Itgax-Cre-mediated deletion of Irf4 that attributed reduced Th2 responses to Irf4-expressing cDC2s (Gao et al. 2013; Kumamoto et al. 2013). Still, it is not clear that the missing population is directly responsible for inducing Th2 responses, and the mechanism underlying these phenomena are unknown. Recent studies suggest that ILC2s promote the migration of $\mathrm{cDCs}$ to draining lymph nodes, and that cDC2s express chemokines that attract memory Th2 cells on rechallenge (Halim et al. 2014, 2016). Further, normal Th2 responses are driven by cytokines, including IL-13, that are produced by ILC2 cells in response to IL-25 produced in tissues, for example, by epithelial tuft cells in response to certain stimuli (Van Dyken et al. 2016; von Moltke et al. 2016). Thus, it is conceivable that Th2 responses may rely on $\mathrm{T}$ cells that reach the tissues in a sufficiently nonpolarized state to respond to this "tissue checkpoint" (Van Dyken et al. 2016). Because BATF3- and Notch2-dependent DCs have been associated with Th1 and Th17 responses, perhaps KLF4-dependent DCs simply provide for activation of $\mathrm{T}$ cells without strong polarization, allowing for flexible T-cell responses in tissues.

\section{pDC Development and Function}

E2-2, encoded by Tcf4, is a member of the $\mathrm{E}$ family of basic helix-loop-helix transcription factors (Kee 2009). In both mice and humans, E2-2 is required for the specification of CDPs to pDCs (Cisse et al. 2008). Induced deletion of E22 in mature pDCs results in the acquisition of cDC-like properties, such as dendritic morphology, MHCII and CD8 $\alpha$ expression, and the ability to induce proliferation of allogeneic $\mathrm{CD} 4^{+} \mathrm{T}$ cells (Ghosh et al. 2010). Deletion of E2-2 in pDCs also induces the expression of ID2. 
D.A. Anderson et al.

MTG16, a transcriptional cofactor of the ETO protein family, represses the expression of ID2 in pre-DCs and mature pDCs (Ghoshi et al. 2014). The proteins encoded by Tcf4 are expressed as multiple isoforms (Corneliussen et al. 1991), TCF4s (short) and TCF4L (long) (Sepp et al. 2011). TCF4L contains activation domain 1 (AD1), which can interact with both p300 and the corepressor RUNX1T1 (Zhang et al. 2004). Within the immune system, TCF4s is expressed in many cells, including cDCs, B cells, and pDCs; however, TCF4L expression is restricted to pDCs (Grajkowska et al. 2017). Loss of TCF4L caused a reduction of pDCs in the BM and spleen similar to that observed in $M \operatorname{tg} 16^{-1-}$ mice. The induction of Tcf4 expression in pDCs is regulated by a proximal $\mathrm{pDC}$-specific $3^{\prime}$ enhancer that requires TCF4 to maintain a positive feedback loop. TCF4L induction occurs at the CDP stage of development, but the stage at which it is required for development remains unclear. This would be aided by the identification of the clonogenic pDC progenitor; however, so far, there has only been identification of populations of BM cells that show relative enrichment for pDCs, and no population that is clonogencially restricted to the pDC lineage has been reported to date (Schlitzer et al. 2011). Similarly, the transcriptional basis for pDC specification and commitment awaits identification.

One mechanism proposed for $\mathrm{pDC}$ specification is the expression of ID2, which is required for $\mathrm{CDC1}$ development. Recently, we and others identified Zeb2, a Zinc-finger homeodomain transcription factor (Vandewalle et al. 2009) to be required for $\mathrm{pDC}$ development (Scott et al. 2016; Wu et al. 2016b). Germline deletion of Zeb2 causes embryonic lethality in mice as a result of its action during the epithelial-mesenchymal transition (Higashi et al. 2002; Van de Putte et al. 2003), which involves the repression of E-cadherin (Comijn et al. 2001; Vandewalle et al. 2005). In the nervous system, ZEB2 regulates myelination by modulating the actions of Smad proteins, which are activated members of the TGF- $\beta$ superfamily known as bone morphogenic proteins (Weng et al. 2012). In oligodendrocyte precursors, Zeb2 expression is low and activated Smads bind P300, a coactivator histone acetyltransferase, inducing expression of negative regulatory genes such as Id2 and Hes1. However, in differentiating oligodendrocytes, OLIG1 and OLIG2 induce the expression of ZEB2, which binds to and represses SmadP300 complexes thus blocking Id2 and Hes1 expression (Weng et al. 2012). Within DC development, ZEB2 appears to act as a negative regulator of ID2. We found that deletion of Zeb2 in DCs using Itgax-Cre caused slightly higher expression of $I d 2$ in $\mathrm{cDC} 2 \mathrm{~s}$ compared with $I d 2$ expression in WT cDC2 cells. Overexpression of Zeb2 in BM cultures stimulated with FLT3L caused strongly increased pDC development while restricting the frequency of $\mathrm{cDC1}$ cells (Wu et al. 2016b). The role of ZEB2 in cDC2s is still unclear. If specification to the $\mathrm{pDC}$ and cDC lineages is dependent $Z e b 2$ and $I d 2$, respectively, it is unclear how cDC2s develop in $I d 2^{-/-}$ mice (Hacker et al. 2003; Kusunoki et al. 2003). In summary, it is unclear currently whether ID2 acts simply to exclude pDC potential from cells arising from the CDP population, for example, by preventing runaway E2-2 expression (Grajkowska et al. 2017) or, alternatively, whether it acts to support $\mathrm{CDC} 1$ development in some way. In either case, the actual mechanism has not been identified.

Other factors have been implicated in pDC development. Deletion of Runx2, a Runt family transcription factor that is required for osteoblast development (Komori et al. 1997; Otto et al. 1997), causes reduced expression of CCR5 on pDCs, thus impairing their egress from the BM to the periphery (Sawai et al. 2013). Previously, it was thought that deletion of Irf8 prevented pDC development (Schiavoni et al. 2002). However, a recent study showed that pDCs develop in Itgax-Cre Irf ${ }^{\mathrm{fl} / \mathrm{fl}}$ mice but exhibit an abnormal phenotype and altered transcriptional profile (Sichien et al. 2016). This result does not rule out a requirement for Irf8 in the development of pDCs prior to the expression of CD11c; however, given the altered phenotype of pDCs in Itgax-Cre $\operatorname{Ir} f 8^{\mathrm{fl} / \mathrm{fl}}$ mice, it is conceivable that pDCs may still be present in Irf $8^{-/}$mice. A reevaluation of the dependence on Irf8 for pDC development may thus be warranted. 
Murine and Human Dendritic Cells

\section{Human DCs}

Recent efforts to identify human counterparts of murine DCs suggest that their development is conserved across species (Dutertre et al. 2014). The current understanding of the cellular stages of DC development in mice, particularly progenitors developing in the BM, has been reviewed recently (Murphy et al. 2016). Identification of the human counterparts has been challenging because of relative limitations in access to samples such as BM compared with mice. Human $\mathrm{CDC} 1 \mathrm{~s}$ are identified by the expression of CD141, Clec9a, and XCR1 (Bachem et al. 2010; Crozat et al. 2010; Poulin et al. 2010). Like murine cDC1s, these cells express IRF8, produce IL-12, and have superior capacity to cross-present (Haniffa et al. 2012). Human cDC2s can be identified by the expression of CD1c and BDCA1, and, like their mouse counterparts, express IRF4, produce IL-23, and induce differentiation of Th17 cells in response to Aspergillus fumigatus (Schlitzer et al. 2013). Recently, cDC2 cells in peripheral blood were segregated into two distinct groups based on CD5 expression (Yin et al. 2017). CD $5^{\text {high }}$ cDC2s expressed high levels of IRF4 and were potent inducers of T-cell activation. The ontogeny of $\mathrm{CD}^{\text {lo }}$ cells, however, appears unclear. $\mathrm{CD}^{\text {lo }}{ }^{\mathrm{DC}}$ express high levels of $M a f B$, which in mice is highly expressed in monocytes and macrophages but not cDCs (Satpathy et al. 2012b; Wu et al. 2016a). A large cohort of human lymphoid tissue samples was used to confirm the broad tissue distribution of $\mathrm{CDC} 1 \mathrm{~s}$ and $\mathrm{cDC} 2 \mathrm{~s}$ and the conservation of $\mathrm{CDC}$ migratory phenotypes between mice and humans based on the expression of CCR7 and higher MHCII (Granot et al. 2017).

With the application of single-cell RNA-Seq (scRNA-Seq), several studies have identified human DC progenitors in BM and blood. Three independent studies described human precDC progenitors with $\mathrm{CDC} 1$ and $\mathrm{CDC} 2$ potential (Breton et al. 2015a,b; See et al. 2017; Villani et al. 2017), using different surface markers (Table 2). However, whether these populations are related has not been tested. A side-by-side comparison of pre-cDCs identified by See et al.
Table 2. Markers of humans pre-cDCs in peripheral blood

\begin{tabular}{lccc}
\hline Surface & $\begin{array}{c}\text { Pre-cDC } \\
\text { (Breton et al. } \\
\text { marker }\end{array}$ & $\begin{array}{c}\text { Pre-cDC } \\
\text { (Villani et al. } \\
\text { 2015a,b) }\end{array}$ & $\begin{array}{c}\text { Pre-cDC } \\
\text { (See et al. } \\
\text { 2017) }\end{array}$ \\
\hline HLA-DR & + & + & + \\
CDllc & lo & & lo \\
CD14 & - & - & - \\
CD34 & - & int & - \\
CD45RA & + & + & + \\
CD100 & $?$ & + & $?$ \\
CD115 & - & - & $?$ \\
CD116 & + & & + \\
CD117 & + & + & - \\
CD123 & int & - & + \\
CD135 & + & - & + \\
\hline
\end{tabular}

Summary of surface marker expression used by three independent groups to identify distinct populations of preclassical dendritic cells (cDCs) in peripheral blood from humans. Question marks indicate that the marker's expression was not reported in the study.

and Breton et al. showed that the former was more abundant, had higher expression of CD303, and lower expression of CD117 (See et al. 2017). However, it has been suggested that pre-cDCs are heterogeneous and composed of cells already specified to each subset of the cDC lineage, similar to that observed in mice (Breton et al. 2016; Grajales-Reyes et al. 2015). Along these lines, progenitors with predominantly $\mathrm{cDC} 1$ or $\mathrm{CDC} 2$ potential have also been identified (Table 3). The first set of committed pre-cDC progenitors were distinguished based on surface expression of CD172a, CDC1 progenitors being $\mathrm{CD} 172 \mathrm{a}^{-}$and $\mathrm{cDC} 2$ progenitors $\mathrm{CD}_{172 \mathrm{a}^{+}}$(Breton et al. 2016). See et al. (2017) independently defined two populations of precDCs that are $\mathrm{CD}_{3} 3^{+} \mathrm{CD} 45 \mathrm{RA}^{+} \mathrm{CD} 123^{\mathrm{lo}}$. The first is $\mathrm{CADM}^{+}$and gives rise to $\mathrm{CDC} 1 \mathrm{~s}$, and the second is $\mathrm{CD} \mathrm{c}^{+}$and gives rise to $\mathrm{CDC} 2 \mathrm{~s}$ (See et al. 2017). As defined by See et al. (2017), circulating pre-cDC1 and pre-cDC2 cells were morphologically similar to mature $\mathrm{CDC} 1$ and cDC2, secreted cytokines after TLR activation, and induced $\mathrm{T}$-cell proliferation during allogeneic responses in vitro.

A novel DC population in circulation identified by scRNA-Seq has recently been proposed and is referred to as the AS-DC based on the 
D.A. Anderson et al.

Table 3. Markers of cDC1 and cDC2 committed human pre-cDCs

\begin{tabular}{lcccc}
\hline Surface marker & $\begin{array}{c}\text { Pre-cDC1 } \\
\text { (Breton et al. 2016) }\end{array}$ & $\begin{array}{c}\text { Pre-cDC1 } \\
\text { (See et al. 2017) }\end{array}$ & $\begin{array}{c}\text { Pre-cDC2 } \\
\text { (Breton et al. 2016) }\end{array}$ & $\begin{array}{c}\text { Pre-cDC2 } \\
\text { (See et al. 2017) }\end{array}$ \\
\hline HLA-DR & + & + & + & + \\
Cadm1 & $?$ & + int & $?$ & - \\
CD1c & - & - & - & + \\
CD14 & - & - & - & - \\
CD33 & $?$ & + & $?$ & + \\
CD34 & - & - & - & - \\
CD45RA & + & + & + & + \\
CD115 & - & $?$ & $?$ & $?$ \\
CD116 & + & $?$ & + & $?$ \\
CD117 & + int & $+/-$ & - & $?$ \\
CD123 & - & + & + & - \\
CD135 & + & $?$ & + & + \\
CD172a & - & + int & $?$ \\
\hline
\end{tabular}

Summary of flow cytometry analysis of surface marker expression used to identify classical dendritic cell (cDC)1 and cDC2 committed pre-cDCs in humans. Question marks indicate the expression for a marker that was not reported for or used to define the population in the study.

expression of AXL and SIGLEC6 (Villani et al. 2017). The gene signatures observed for this population clustered between $\mathrm{pDCs}$ and cDC2s. The authors of the study suggest this population does not represent an intermediate stage of pre-cDCs because DC progenitors do not induce the expression of AXL or SIGLEC6 in culture (Villani et al. 2017). However, the precDC reported by See et al. (2017) expresses the genes that encode these markers. Interrogation of the molecular mechanisms that control human CDC development is limited but gene expression analysis of the progenitors identified to date suggest conservation between mouse and human. For example, specification of $\mathrm{cDC} 1$ and $\mathrm{CDC} 2$ progenitors is associated with the differential expression of known regulators of mouse DC development, including BATF3, ID2, TCF4, IRF4, ZEB2, and IRF8 (Breton et al. 2016; See et al. 2017).

Human pDCs produce high levels of type I interferons (IFNs) during responses to viral infection (Cella et al. 1999; Siegal et al. 1999). They can also activate $\mathrm{CD} 4^{+}$and $\mathrm{CD}^{+} \mathrm{T}$ cells in response to influenza virus (Fonteneau et al. 2003). However, heterogeneity within the bulk $\mathrm{pDC}$ population was later recognized using $\mathrm{CD} 2$ as a marker to distinguish two distinct $\mathrm{pDC}$ populations (Matsui et al. 2009). $\mathrm{CD}^{+}$pDCs secrete high levels of IL-12p40, induce surface expression of CD80, and induce proliferation of naïve allogeneic $\mathrm{CD} 4^{+} \mathrm{T}$ cells. These cells more closely resemble cDCs than pDCs. This $\mathrm{CD} 2^{+}$ population was further refined using CD5 and CD81 to identify the pDC population capable of secreting IL-12 and activating $\mathrm{CD} 4^{+} \mathrm{T}$ cells (Zhang et al. 2017a). A separate study showed that CD56 expression identified a myeloid DC population within the $\mathrm{CD}^{+} \mathrm{pDC}$ gate. This novel population did not produce IFN- $\alpha$, and instead secreted IL-12 and activated T cells. Transcriptomic analysis showed that $\mathrm{CD}^{+}$ $\mathrm{CD} 6^{+}$pDCs were more closely related to cDCs than to pDCs (Yu et al. 2015). Further, transcriptomic analysis of $\mathrm{CD} 56^{+} \mathrm{pDCs}$ showed they were closely related to blastic plasmacytoid DC neoplasms (BPDCNs). These observations were further confirmed by Villani et al. (2017), in which the AS-DC population shared some transcriptomic characteristics with pDCs. Functionally, they were potent inducers of Tcell proliferation and secreted high levels of IL12. These multiple lines of evidence suggest that the cDC-like function attributed to a subset of human pDCs is the result of analysis of heterogeneous populations composed of cDCs and pDCs in early studies of human pDC function. 


\section{CONTEMPORARY ANALYSIS OF PARADIGMS IN CDC DEVELOPMENT AND FUNCTION}

\section{Identification of cDCs in Vivo}

Shared surface marker expression among cells of the myeloid lineage has complicated the discrimination of DC subsets from other myeloid lineages. Recent analyses have proposed a simplified set of markers to discriminate DC subsets across tissues by defining $\mathrm{CDCs}$ as $\mathrm{Lin}^{-} \mathrm{CD} 11 \mathrm{c}^{+}$ $\mathrm{MHCII}^{+} \mathrm{CD} 26^{+} \mathrm{CD}^{-} 4^{-}$, among which $\mathrm{cDC}$ s and $\mathrm{cDC} 2 \mathrm{~s}$ can be identified as $\mathrm{XCR}^{+}$and CD172a ${ }^{+}$, respectively (Guilliams et al. 2016). Surface-marker-independent methods of discriminating lineages have been helpful in resolving the origin of myeloid cells in vivo. Expression of the transcription factor, ZBTB46, is restricted to the $\mathrm{CDC}$ lineage and can be used to identify cDCs and their progenitors in lymphoid and nonlymphoid tissues (Satpathy et al. 2012a; Grajales-Reyes et al. 2015). Alternatively, the transcription factor MafB is expressed by cells of the monocyte and macrophage lineage (Aziz et al. 2009; Gautier et al. 2012). A novel lineage-tracing reagent, MafB-mCherry-Cre mice, marks cells that express $\mathrm{MafB}\left(\mathrm{mCherry}^{+}\right)$ or have expressed MafB during development (YFP $^{+}$when crossed to R26-stop-YFP mice), and can thus be used in combination with Zbtb46 to discriminate between macrophage and DC lineages in vivo (Wu et al. 2016a). Interestingly, it was found that, among the tissues examined, Langerhans cells (LCs) in skin-draining lymph nodes were the only lineage to express $Z b t b 46$ and also be marked by Mafb-driven lineage tracing.

\section{Mo-DCs and GM-DCs}

Numerous studies have suggested that under inflammatory conditions monocytes have the potential to differentiate into cDCs. From in vitro studies, it is known that monocytes from mice or humans cultured with granulocyte macrophage colony-stimulating factor (GMCSF) and IL-4, referred to as Mo-DCs, acquire characteristics of cDCs (Caux et al. 1992; Inaba et al. 1992, 1993; Romani et al. 1994; Sallusto and Lanzavecchia 1994). Similarities include the expression of canonical surface markers, such as CD11c and MHCII (Leon et al. 2004), and DC-specific transcription factors, such as Zbtb46 and Mycl1 (Satpathy et al. 2012a; Wumesh et al. 2014). Upon treatment of GM-CSF, monocytes rapidly induce the expression of IRF4 (Lehtonen et al. 2005), which is required for their differentiation into $\mathrm{CDC}$-like cells that express Zbtb46 and MHCII (Briseno et al. 2016). Mo-DCs have the ability to cross-prime CD8 T cells to cell-associated antigens in vitro; however, cross-presentation by the subset specialized for this activity in vivo, cDC1s, is Irf4-independent (Vander et al. 2014; Briseno et al. 2016). GM-CSF-derived DCs (GM-DCs) have been used extensively in studies surveying DC function. Many of the known actors involved in cross-presentation were first identified in GMDCs and are reviewed here (Theisen and Murphy 2017). However, it was recently reported that BM cultures stimulated with GM-CSF produce heterogeneous populations and has thus casted doubt over physiological relevance GMDCs to in vivo cDC subsets (Helft et al. 2015). To obtain populations of pDCs and $\mathrm{cDCs}$ that more closely resemble in vivo counterparts, an alternative in vitro culture system that uses whole BM or purified progenitors in Flt3L was developed (Naik et al. 2005). We recently identified Rab43 to be involved in the cross-presentation of cell-associated antigen by cDC1s but not by GM-DCs (Kretzer et al. 2016). Therefore, it may be necessary to evaluate the function of molecules previously reported in GM-DCs to regulate vesicular trafficking and cross-presentation, including but not limited to RAC2 (Savina et al. 2009), RAB11A (Nair-Gupta et al. 2014), RAB3B (Zou et al. 2009), and SEC22B (Cebrian 2011).

The precise role of GM-DCs in promoting $\mathrm{CD}^{+} \mathrm{T}$-cell responses via cross-presentation is unclear because Zbtb46-expressing Mo-DCs have yet to be distinguished in vivo from bona fide $\mathrm{CD} 1 \mathrm{bb}^{+} \mathrm{DCs}$, and thus a model to selectively deplete them is unavailable. Recent work that replicated in vivo models of putative Mo-DC differentiation by house dust mite challenge did not identify Zbtb46-expressing cells that 
D.A. Anderson et al.

were marked by $M a f B$-driven lineage tracing (Wu et al. 2016a). Therefore, the developmental origins of the Mo-DCs in vivo remain elusive. Notwithstanding, GM-DCs have been demonstrated to be a viable option in the generation of tumor vaccines (Linette and Carreno 2013). Human Mo-DCs generated with GM-CSF and IL-4 have been used as the basis for therapeutic cancer vaccines (Palucka and Banchereau 2013; Carreno et al. 2015). Vaccines based on human Mo-DCs pulsed with tumor-specific peptides can initiate CD8 $\mathrm{T}$-cell responses and induce clinical responses in melanoma, renal cell carcinoma, and malignant glioma (Nestle et al. 1998; Holtl et al. 1999; Thurner et al. 1999; Timmerman et al. 2002). Human Mo-DCs generated ex vivo can also elicit broad $\mathrm{CD} 8^{+} \mathrm{T}$-cell responses against tumor antigens, and to a class of subdominant neoantigens in patients with melanoma (Carreno et al. 2015).

\section{cDC Maturation}

An additional area of study to emerge from the use of GM-DCs is DC maturation. The term "mature" was first used to describe the adherent fraction of DCs isolated from the spleen of mice (Steinman and Cohn 1973). The process of "maturation" was later described as the acquisition of T-cell stimulatory capacity of LCs and DCs after isolation and ex vivo culture (Schuler et al. 1985; Witmer-Pack et al. 1987; Heufler et al. 1988). The capacity to stimulate $\mathrm{T}$ cells was correlated with the induction of costimulatory molecules, such as CD80 and CD86 (Inaba et al. 1994), and chemokine receptors, such as CCR7 (Sallusto et al. 1998; Sozzani et al. 1998). Immature DCs in vitro most closely resemble resident DCs in vivo and are identified as CD11 $c^{\text {hi }}$ $\mathrm{MHCII}^{+}$. Mature DCs in vitro most closely resemble migratory DCs in vivo and are identified as $\mathrm{CD} 11 \mathrm{c}^{+} \mathrm{MHCII}{ }^{\text {hi }}$. Consistent with this correlation, migratory DCs in vivo express elevated levels of the canonical maturation markers CCR7, CD80, CD86, and CD40. CCR7 is required for the migration of $\mathrm{cDCs}$ to draining lymphoid organs (Forster et al. 1999; Ohl et al. 2004), CD80 and CD86 are required for stimulation of naïve T cells (Steinman et al. 2003), and
CD40 is required to receive CD4 T-cell help (Bennett et al. 1998; Schoenberger et al. 1998). Therefore, the study of maturation in vitro has led to important in vivo discoveries regarding fundamental DC biology. However, recent analysis of maturation in vivo calls for a revision of previously established paradigms regarding functional differences between immature and mature DCs.

Low expression of costimulatory molecules on immature DCs formed the basis for a hypothesis that immature DCs are specialized at tolerance induction and have thus been referred to as tolerogenic (Morelli and Thomson 2007). Recent in vivo evidence is contrary to this distinction. It was recently shown that mature cDC1s are the sole population capable of crosspresenting thymic epithelial-cell-derived selfantigens, and that BATF3-dependent $\mathrm{cDC} 1 \mathrm{~s}$ are required to induce a subset of Aire-dependent natural regulatory $\mathrm{T}$ (Treg) cells (Perry et al. 2014; Ardouin et al. 2016). Peripheral Treg induction in the small intestine lamina propia is also induced by $\mathrm{CDC} 1 \mathrm{~s}$ that have taken up hostderived antigen and migrate to draining lymph nodes. These cells express higher levels of $\mathrm{Ccr} 7$ and undergo transcriptional reprogramming associated with maturation (Cummings et al. 2016). This is consistent with results from the examination of draining lymph nodes of the oral mucosa, where migratory $\mathrm{cDC} 1 \mathrm{~s}$ are most efficient at inducing oral tolerance to dietary antigens (Esterhazy et al. 2016). Contrary to a role for $\mathrm{CDC} 1 \mathrm{~s}$ in the induction of tolerance, $\mathrm{cDC} 1 \mathrm{~s}$ can also be essential for the initiation of autoimmunity in mice with genetic backgrounds predisposed to the development of diabetes (Ferris et al. 2014).

Given that functional distinctions between immature and mature DCs may not be consistent with phenomena that occur in vivo, the process of maturation may be better conceptualized as a stage of $\mathrm{cDC}$ development. $\mathrm{cDC}$ progenitors are known to egress from the $\mathrm{BM}$ specified to either the $\mathrm{CDC1}$ or $\mathrm{CDC} 2$ lineage (Grajales-Reyes et al. 2015). In peripheral tissues, immature cDCs exhibit phenotypes associated with cell division and proliferation (Liu et al. 2007). Work to identify the factors that 
regulate DC proliferation remains an active area of research. In secondary lymphoid organs, deficiency in the DC-specific transcription factor, $\mathrm{L}-\mathrm{Myc}$, results in a reduction in the number of $\mathrm{cDC} 1 \mathrm{~s}$, reduction in DNA replication associated with cell division, reduction in priming of antigen-specific CD8 T cells, and enhanced resistance to infection with $L$. monocytogenes (Wumesh et al. 2014). The growth factor, Flt3L, has been shown to expand BM progenitors of $\mathrm{CDCs}$ and increase the population size of cDCs in lymphoid organs (Waskow et al. 2008). Although a requirement for GM-CSF in CDC1 development is debated (Edelson et al. 2011b; Greter et al. 2012), treatment with GM-CSF in vivo and in vitro in combination with Flt3L is sufficient to expand populations of cDCs (Daro et al. 2000; Mayer et al. 2014).

The extent to which local growth factor concentrations and milieus influence proliferation of cDCs at steady state and during inflammation in peripheral tissues is not well understood, and may be made redundant by constant recruitment of progenitors from the BM (Liu and Nussenzweig 2010). Whole transcriptome analysis of mature $\mathrm{CCR}^{+}$and immature $\mathrm{CCR}^{-}{ }^{-} \mathrm{CDC} 1 \mathrm{~s}$ sorted from the thymus and spleen at steady state revealed broad transcriptional reprogramming that includes differential expression of genes associated with exit from the cell cycle (Ardouin et al. 2016). Similar transcriptional changes have been detected in cDCs from a variety of tissues when resident and migratory counterparts are compared (Manh et al. 2013). Identification of cells that have undergone cellcycle exit or entered a state of quiescence is commonly used to uncover stages at which terminal differentiation occurs during the ontogeny of cellular lineages (Massague 2004; Buttitta and Edgar 2007; Coller 2011). Therefore, cell-cycle exit on $\mathrm{CDC}$ maturation suggests that this process represents a terminal stage in the developmental program of cDCs. The factors necessary to induce maturation in vivo remain largely unknown, and much of the work conducted to date has focused on the cell-extrinsic influence of host- and commensal-derived stimuli.

Both host- and microbiota-derived factors have been reported to be sufficient to induce
DC maturation. In a model of vaccination using mice deficient in IFNAR, it was shown that type I IFN in response to poly-IC acted directly on DCs to induce maturation of splenic DCs and induce Th1 immunity to a model antigen of HIV (Longhi et al. 2009). In models of viral infection and tumor rejection, the action of type I IFN on cDCs was required for optimal CD8 T-cell priming and Th1-cell polarization (Brewitz et al. 2017; Diamond et al. 2011; Fuertes et al. 2011). Recent whole transcriptome analysis has demonstrated that transcriptional reprogramming is conserved between maturation at homeostasis or under inflammatory conditions of poly-IC injection or viral infection, and occurs independently of IFNAR signaling (Ardouin et al. 2016). Although signaling through IFNAR may be sufficient to induce maturation in the spleen (Longhi et al. 2009), where at least $90 \%$ of DCs exhibit an immature phenotype (Ardouin et al. 2016), such signals are not necessary to execute the transcriptional program that occurs during this process.

Signaling cascades initiated by engagement of the receptors for IL-1 $\beta$, tumor necrosis factor $\alpha$ (TNF- $\alpha)$, CD40L, and LT converge on activation of canonical and noncanonical nuclear factor (NF) $-\kappa B$ (Jost and Ruland 2007). As discussed above, it was recently shown that a requirement of RelB in the development of cDCs is largely cell-extrinsic, with the exception of a splenic cDC2 subset that is also Notch2- and LT $\beta R$-dependent (Kabashima et al. 2005; Satpathy et al. 2013; Briseno et al. 2017). However, this does not rule out a DC-intrinsic role for RelB or the remaining NF- $\kappa \mathrm{B}$ family members in $\mathrm{CDC}$ maturation. In vivo analysis of p50-deficient mice showed no effect on the expression of CD80 or CD86; however, they have a defect in Th2 cell differentiation during helminth infection, which is now known to be regulated by the KLF4-dependent cDC2 subset (Artis et al. 2005; Tussiwand et al. 2015). An independent study also showed that cRel, p50, and RelA are dispensable for development of cDCs and the expression of CD80 and CD86. However, the deletion of p50 and RelA together led to a significant loss of CD11 $c^{+}$cells in the spleen (Ouaaz et al. 2002). Therefore, NF- $\mathrm{KB}$ family members may have 
D.A. Anderson et al.

compensatory roles in cDC development and function. Defining such combinatorial complexity in NF- $\mathrm{KB}$ activity has been difficult to define in vivo, because up to 15 dimer combinations are possible with 13 reported to date (Smale 2012; Zhang et al. 2017b). Modules of genes that are known NF- $\mathrm{KB}$ targets are differentially expressed during maturation (Manh et al. 2013; Ardouin et al. 2016); however, definition of the cell-intrinsic requirements for NF$\mathrm{\kappa B}$ in $\mathrm{CDC}$ function remains a hurdle to overcome in this field.

Homeostatic interactions between commensal microbiota and the host-immune system have been linked to various immunological disorders in patients with mutations of pattern-recognition receptors (PRRs) (Hooper et al. 2012). Direct signals from microbiota acting on DCs at steady state and during infection have been suggested to regulate DC maturation (Steinman et al. 2003). Although there is mounting evidence for the regulation of immune homeostasis through interactions between the host and commensal microbiota (Belkaid and Hand 2014), evidence for the regulation of DC maturation is limited. DC-specific deletion of Traf6, which encodes a signaling adaptor downstream of various PRRs, results in defective inflammatory cytokine production on stimulation with $\mathrm{CpG}$ and LPS. These mice also develop spontaneous inflammation of the small intestine that is associated with aberrant Th2 cell priming, which can be rescued by treatment with antibiotics (Han et al. 2013). Traf6 ${ }^{-1-}$ mice have defective induction of maturation markers on DCs in vivo when treated with LPS or CD40L and, therefore, it was proposed to be necessary for DC maturation (Kobayashi et al. 2003). However, in single and double knockout mice of $M y D 88$ and Ticam1, no effect on the development or maturation of DCs was observed (Wilson et al. 2008). Such conflicting results are difficult to interpret in light of complex cross talk that may establish redundancy in signaling pathways downstream of PRRs (Lee and Kim 2007). Therefore, ablation of commensal microbiota is widely used as a strategy to probe the impact of steady-state microbial signals on immune homeostasis. To that end, WT specific pathogen-free (SPF) and germ-free mice showed no significant differences in the core transcriptional program associated with maturation in vivo for thymic $\mathrm{CDC} 1 \mathrm{~s}$ (Ardouin et al. 2016). In addition, the core maturation programs that occur at homeostasis or under inflammation induced by poly-IC or STAg overlap broadly (Ardouin et al. 2016). As opposed to a model that focuses on cell-extrinsic stimuli, representation of maturation as a cell-intrinsic developmental program can provide an alternative framework to discover novel mechanisms that regulate DC development and function.

\section{CONCLUSION}

In summary, analysis of the molecular events that underlie distinct forms of DCs in the mouse have advanced over the past 8 years, with the identification of several transcription factors required for some, but not all, DC subsets. Notably, while several factors appear to be required for $\mathrm{CDC} 1$ and $\mathrm{pDC}$ development, there has been no single factor whose ablation selectively prevents cDC2 development. It is true that Notch2 is required for the normal functioning of $\mathrm{cDC} 2$ in response to certain pathogens and that KLF4 is required for $\mathrm{CDC} 2$ support of Th2 type responses, but, in each case, cDC2 cells develop in the absence of these factors. It is not clear that these results mean that $\mathrm{cDC} 2$ development is a "default" pathway, because it may turn out that a mechanism will be found that is necessary for development of all forms of cDC2. Progress arising from analysis of the murine system has also provided a basis for analysis of human DCs, which now are recognized as being structurally similar to their murine counterparts, at least in certain fundamental ways. These studies in both systems promise to provide a basis for future rational therapeutic interventions to complement the current progress in immunotherapy.

\section{REFERENCES}

\footnotetext{
Aliberti J, Schulz O, Pennington DJ, Tsujimura H, Sousa RE, Ozato K, Sher A. 2003. Essential role for ICSBP in the in vivo development of murine $\mathrm{CD} 8 \alpha^{+}$dendritic cells. Blood 101: 305-310.
} 
Ardouin L, Luche H, Chelbi R, Carpentier S, Shawket A, Montanana AF, Santa MC, Grenot P, Alexandre Y, Gregoire C, et al. 2016. Broad and largely concordant molecular changes characterize tolerogenic and immunogenic dendritic cell maturation in thymus and periphery. Immunity 45: 305-318.

Artis D, Kane CM, Fiore J, Zaph C, Shapira S, Joyce K, Macdonald A, Hunter C, Scott P, Pearce EJ. 2005. Dendritic cell-intrinsic expression of NF- $\mathrm{\kappa B} 1$ is required to promote optimal Th2 cell differentiation. J Immunol 174: 7154-7159.

Auffray C, Fogg DK, Narni-Mancinelli E, Senechal B, Trouillet C, Saederup N, Leemput J, Bigot K, Campisi L, Abitbol $\mathrm{M}$, et al. 2009. $\mathrm{CX}_{3} \mathrm{CR} 1^{+} \mathrm{CD} 115^{+} \mathrm{CD} 135^{+}$common macrophage/DC precursors and the role of CX3CR1 in their response to inflammation. J Exp Med 206: 595-606.

Aziz A, Soucie E, Sarrazin S, Sieweke MH. 2009. MafB/c-Maf deficiency enables self-renewal of differentiated functional macrophages. Science 326: 867-871.

Bachem A, Guttler S, Hartung E, Ebstein F, Schaefer M, Tannert A, Salama A, Movassaghi K, Opitz C, Mages HW, et al. 2010. Superior antigen cross-presentation and XCR1 expression define human $\mathrm{CD} 11 \mathrm{c}^{+} \mathrm{CD} 141^{+}$ cells as homologues of mouse $\mathrm{CD} 8^{+}$dendritic cells. $J$ Exp Med 207: 1273-1281.

Belkaid Y, Hand TW. 2014. Role of the microbiota in immunity and inflammation. Cell 157: 121-141.

Bennett SR, Carbone FR, Karamalis F, Flavell RA, Miller JF, Heath WR. 1998. Help for cytotoxic-T-cell responses is mediated by CD40 signalling. Nature 393: 478-480.

Breton G, Lee J, Liu K, Nussenzweig MC. 2015a. Defining human dendritic cell progenitors by multiparametric flow cytometry. Nat Protoc 10: 1407-1422.

Breton G, Lee J, Zhou YJ, Schreiber JJ, Keler T, Puhr S, Anandasabapathy N, Schlesinger S, Caskey M, Liu K, et al. 2015b. Circulating precursors of human $\mathrm{CD}^{+} \mathrm{c}^{+}$and CD141 ${ }^{+}$dendritic cells. J Exp Med 212: 401-413.

Breton G, Zheng S, Valieris R, da Silva IT, Satija R, Nussenzweig MC. 2016. Human dendritic cells (DCs) are derived from distinct circulating precursors that are precommitted to become CD1c ${ }^{+}$and $\mathrm{CD} 141^{+}$DCs. J Exp Med 213: 2861-2870.

Brewitz A, Eickhoff S, Dahling S, Quast T, Bedoui S, Kroczek RA, Kurts C, Garbi N, Barchet W, Iannacone M, et al. 2017. CD $8^{+}$T cells orchestrate pDC-XCR $1^{+}$dendritic cell spatial and functional cooperativity to optimize priming. Immunity 46: 205-219.

Briseno CG, Haldar M, Kretzer NM, Wu X, Theisen DJ, Wumesh KC, Durai V, Grajales-Reyes GE, Iwata A, Bagadia P, et al. 2016. Distinct transcriptional programs control cross-priming in classical and monocyte-derived dendritic cells. Cell Rep 15: 2462-2474.

Briseno CG, Gargaro M, Durai V, Davidson JT, Theisen DJ, Anderson DA III, Novack DV, Murphy TL, Murphy KM. 2017. Deficiency of transcription factor RelB perturbs myeloid and DC development by hematopoietic-extrinsic mechanisms. Proc Natl Acad Sci 114: 3957-3962.

Burkly L, Hession C, Ogata L, Reilly C, Marconi LA, Olson D, Tizard R, Cate R, Lo D. 1995. Expression of relB is required for the development of thymic medulla and dendritic cells. Nature 373: 531-536.
Buttitta LA, Edgar BA. 2007. Mechanisms controlling cell cycle exit upon terminal differentiation. Curr Opin Cell Biol 19: 697-704.

Carreno BM, Magrini V, Becker-Hapak M, Kaabinejadian S, Hundal J, Petti AA, Ly A, Lie WR, Hildebrand WH, Mardis ER, et al. 2015. Cancer immunotherapy. A dendritic cell vaccine increases the breadth and diversity of melanoma neoantigen-specific T cells. Science 348: 803-808.

Caux C, Dezutter-Dambuyant C, Schmitt D, Banchereau J. 1992. GM-CSF and TNF- $\alpha$ cooperate in the generation of dendritic Langerhans cells. Nature 360: 258-261.

Cella M, Jarrossay D, Facchetti F, Alebardi O, Nakajima H, Lanzavecchia A, Colonna M. 1999. Plasmacytoid monocytes migrate to inflamed lymph nodes and produce large amounts of type I interferon [see comments]. Nat Med 5: 919-923.

Cisse B, Caton ML, Lehner M, Maeda T, Scheu S, Locksley R, Holmberg D, Zweier C, den Hollander NS, Kant SG, et al. 2008. Transcription factor E2-2 is an essential and specific regulator of plasmacytoid dendritic cell development 1. Cell 135: 37-48.

Coller HA. 2011. Cell biology. The essence of quiescence. Science 334: 1074-1075.

Comijn J, Berx G, Vermassen P, Verschueren K, van Grunsven L, Bruyneel E, Mareel M, Huylebroeck D, Van Roy F. 2001. The two-handed E box binding zinc finger protein SIP1 downregulates E-cadherin and induces invasion. Mol Cell 7: 1267-1278.

Corneliussen B, Thornell A, Hallberg B, Grundstrom T. 1991. Helix-loop-helix transcriptional activators bind to a sequence in glucocorticoid response elements of retrovirus enhancers. J Virol 65: 6084-6093.

Crozat K, Guiton R, Contreras V, Feuillet V, Dutertre CA, Ventre E, Vu Manh TP, Baranek T, Storset AK, Marvel J, et al. 2010. The XC chemokine receptor 1 is a conserved selective marker of mammalian cells homologous to mouse CD8 $\alpha^{+}$dendritic cells. J Exp Med 207: 1283-1292.

Cummings RJ, Barbet G, Bongers G, Hartmann BM, Gettler K, Muniz L, Furtado GC, Cho J, Lira SA, Blander JM. 2016. Different tissue phagocytes sample apoptotic cells to direct distinct homeostasis programs. Nature 539: 565569.

Daro E, Pulendran B, Brasel K, Teepe M, Pettit D, Lynch DH, Vremec D, Robb L, Shortman K, McKenna HJ, et al. 2000. Polyethylene glycol-modified GM-CSF expands CD $11 b^{\text {high }} \mathrm{CD} 11 \mathrm{c}^{\text {high }}$ but notCD $11 b^{\text {low }} \mathrm{CD} 11 \mathrm{c}^{\text {high }}$ murine dendritic cells in vivo: A comparative analysis with Flt3 ligand. J Immunol 165: 49-58.

DeKoning J, DiMolfetto L, Reilly C, Wei Q, Havran WL, Lo D. 1997. Thymic cortical epithelium is sufficient for the development of mature $\mathrm{T}$ cells in relB-deficient mice. $J$ Immunol 158: 2558-2566.

De Silva NS, Silva K, Anderson MM, Bhagat G, Klein U. 2016. Impairment of mature $B$ cell maintenance upon combined deletion of the alternative NF- $\kappa B$ transcription factors RELB and NF- $\kappa$ B2 in B Cells. J Immunol 196: 2591-2601.

Diamond MS, Kinder M, Matsushita H, Mashayekhi M, Dunn GP, Archambault JM, Lee H, Arthur CD, White JM, Kalinke U, et al. 2011. Type I interferon is selectively required by dendritic cells for immune rejection of tumors. J Exp Med 208: 1989-2003. 
D.A. Anderson et al.

Dutertre CA, Wang LF, Ginhoux F. 2014. Aligning bona fide dendritic cell populations across species. Cell Immunol 291: 3-10.

Edelson BT, Wumesh KC, Juang R, Kohyama M, Benoit LA, Klekotka PA, Moon C, Albring JC, Ise W, Michael DG, et al. 2010. Peripheral $\mathrm{CD} 103^{+}$dendritic cells form a unified subset developmentally related to $\mathrm{CD} 8 \alpha^{+}$conventional dendritic cells. J Exp Med 207: 823-836.

Edelson BT, Bradstreet TR, Hildner K, Carrero JA, Frederick KE, Wumesh KC, Belizaire R, Aoshi T, Schreiber RD, Miller MJ, et al. 2011a. CD8 ${ }^{+}$dendritic cells are an obligate cellular entry point for productive infection by Listeria monocytogenes. Immunity 35: 236-248.

Edelson BT, Bradstreet TR, Wumesh KC, Hildner K, Herzog JW, Sim J, Russell JH, Murphy TL, Unanue ER, Murphy KM. 2011b. Batf3-dependent CD11b ${ }^{\text {low/- }}$ peripheral dendritic cells are GM-CSF-independent and are not required for Th cell priming after subcutaneous immunization. PLOS ONE 6: e25660.

Esterhazy D, Loschko J, London M, Jove V, Oliveira TY, Mucida D. 2016. Classical dendritic cells are required for dietary antigen-mediated induction of peripheral Treg cells and tolerance. Nat Immunol 17: 545-555.

Everts B, Tussiwand R, Dreesen L, Fairfax KC, Huang SC, Smith AM, O'Neill CM, Lam WY, Edelson BT, Urban JF Jr, et al. 2016. Migratory CD103 ${ }^{+}$dendritic cells suppress helminth-driven type 2 immunity through constitutive expression of IL-12. J Exp Med 213: 35-51.

Fasnacht N, Huang HY, Koch U, Favre S, Auderset F, Chai Q, Onder L, Kallert S, Pinschewer DD, MacDonald HR, et al. 2014. Specific fibroblastic niches in secondary lymphoid organs orchestrate distinct Notch-regulated immune responses. J Exp Med 211: 2265-2279.

Ferris ST, Carrero JA, Mohan JF, Calderon B, Murphy KM, Unanue ER. 2014. A minor subset of Batf3-dependent antigen-presenting cells in islets of Langerhans is essential for the development of autoimmune diabetes. Immunity 41: 657-669.

Fogg DK, Sibon C, Miled C, Jung S, Aucouturier P, Littman DR, Cumano A, Geissmann F. 2006. A clonogenic bone marrow progenitor specific for macrophages and dendritic cells. Science 311: 83-87.

Fonteneau JF, Gilliet M, Larsson M, Dasilva I, Munz C, Liu YJ, Bhardwaj N. 2003. Activation of influenza virus-specific $\mathrm{CD}^{+}$and $\mathrm{CD} 8{ }^{+} \mathrm{T}$ cells: A new role for plasmacytoid dendritic cells in adaptive immunity. Blood 101: 35203526.

Forster R, Schubel A, Breitfeld D, Kremmer E, Renner-Muller I, Wolf E, Lipp M. 1999. CCR7 coordinates the primary immune response by establishing functional microenvironments in secondary lymphoid organs. Cell 99: 2333.

Fuertes MB, Kacha AK, Kline J, Woo SR, Kranz DM, Murphy KM, Gajewski TF. 2011. Host type I IFN signals are required for antitumor $\mathrm{CD}^{+} \mathrm{T}$ cell responses through CD8 $\alpha^{+}$dendritic cells. J Exp Med 208: 2005-2016.

Gao Y, Nish SA, Jiang R, Hou L, Licona-Limon P, Weinstein JS, Zhao H, Medzhitov R. 2013. Control of T helper 2 responses by transcription factor IRF4-dependent dendritic cells. Immunity 39: 722-732.

Gautier EL, Shay T, Miller J, Greter M, Jakubzick C, Ivanov S, Helft J, Chow A, Elpek KG, Gordonov S, et al. 2012. Gene- expression profiles and transcriptional regulatory pathways that underlie the identity and diversity of mouse tissue macrophages. Nat Immunol 13: 1118-1128.

Gerloni M, Lo D, Ballou WT, Zanetti M. 1998a. Immunological memory after somatic transgene immunization is positively affected by priming with GM-CSF and does not require bone marrow-derived dendritic cells. Eur J Immunol 28: 1832-1838.

Gerloni M, Lo D, Zanetti M. 1998b. DNA immunization in relB-deficient mice discloses a role for dendritic cells in IgM $\rightarrow$ IgG1 switch in vivo. Eur J Immunol 28: 516-524.

Ghosh HS, Cisse B, Bunin A, Lewis KL, Reizis B. 2010. Continuous expression of the transcription factor e2-2 maintains the cell fate of mature plasmacytoid dendritic cells. Immunity 33: 905-916.

Ghosh HS, Ceribelli M, Matos I, Lazarovici A, Bussemaker HJ, Lasorella A, Hiebert SW, Liu K, Staudt LM, Reizis B. 2014. ETO family protein Mtg16 regulates the balance of dendritic cell subsets by repressing Id2. J Exp Med 211: 1623-1635.

Grajales-Reyes GE, Iwata A, Albring J, Wu X, Tussiwand R, Wumesh KC, Kretzer NM, Briseno CG, Durai V, Bagadia P, et al. 2015. Batf3 maintains autoactivation of Irf8 for commitment of a CD8 $\alpha^{+}$conventional DC clonogenic progenitor. Nat Immunol 16: 708-717.

Grajkowska LT, Ceribelli M, Lau CM, Warren ME, Tiniakou I, Nakandakari HS, Bunin A, Haecker H, Mirny LA, Staudt LM, et al. 2017. Isoform-specific expression and feedback regulation of E protein TCF4 control dendritic cell lineage specification. Immunity 46: 65-77.

Granot T, Senda T, Carpenter DJ, Matsuoka N, Weiner J, Gordon CL, Miron M, Kumar BV, Griesemer A, Ho SH, et al. 2017. Dendritic cells display subset and tissue-specific maturation dynamics over human life. Immunity 46: 504-515.

Greter M, Helft J, Chow A, Hashimoto D, Mortha A, AgudoCantero J, Bogunovic M, Gautier EL, Miller J, Leboeuf M, et al. 2012. GM-CSF controls nonlymphoid tissue dendritic cell homeostasis but is dispensable for the differentiation of inflammatory dendritic cells. Immunity 36: 1031-1046.

Guilliams M, Ginhoux F, Jakubzick C, Naik SH, Onai N, Schraml BU, Segura E, Tussiwand R, Yona S. 2014. Dendritic cells, monocytes and macrophages: A unified nomenclature based on ontogeny. Nat Rev Immunol 14: 571-578.

Guilliams M, Dutertre CA, Scott CL, McGovern N, Sichien D, Chakarov S, Van Gassen S, Chen J, Poidinger M, De Prijck S, et al. 2016. Unsupervised high-dimensional analysis aligns dendritic cells across tissues and species. Immunity 45: 669-684.

Hacker C, Kirsch RD, Ju XS, Hieronymus T, Gust TC, Kuhl C, Jorgas T, Kurz SM, Rose-John S, Yokota Y, et al. 2003. Transcriptional profiling identifies Id2 function in dendritic cell development. Nat Immunol 4: 380-386.

Halim TY, Steer CA, Matha L, Gold MJ, Martinez-Gonzalez I, McNagny KM, McKenzie AN, Takei F. 2014. Group 2 innate lymphoid cells are critical for the initiation of adaptive T helper 2 cell-mediated allergic lung inflammation. Immunity 40: 425-435.

Halim TY, Hwang YY, Scanlon ST, Zaghouani H, Garbi N, Fallon PG, McKenzie AN. 2016. Group 2 innate lym- 
phoid cells license dendritic cells to potentiate memory $\mathrm{T}_{\mathrm{H}} 2$ cell responses. Nat Immunol 17: 57-64.

Han D, Walsh MC, Cejas PJ, Dang NN, Kim YF, Kim J, Charrier-Hisamuddin L, Chau L, Zhang Q, Bittinger K, et al. 2013. Dendritic cell expression of the signaling molecule TRAF6 is critical for gut microbiota-dependent immune tolerance. Immunity 38: 1211-1222.

Haniffa M, Shin A, Bigley V, McGovern N, Teo P, See P, Wasan PS, Wang XN, Malinarich F, Malleret B, et al. 2012. Human tissues contain CD $141^{\text {hi }}$ cross-presenting dendritic cells with functional homology to mouse $\mathrm{CD}_{103}{ }^{+}$nonlymphoid dendritic cells. Immunity 37: 60-73.

Helft J, Bottcher J, Chakravarty P, Zelenay S, Huotari J, Schraml BU, Goubau D, Sousa RE. 2015. GM-CSF mouse bone marrow cultures comprise a heterogeneous population of $\mathrm{CD} 11 \mathrm{c}^{+} \mathrm{MHCII}^{+}$macrophages and dendritic cells. Immunity 42: 1197-1211.

Heufler C, Koch F, Schuler G. 1988. Granulocyte/macrophage colony-stimulating factor and interleukin 1 mediate the maturation of murine epidermal Langerhans cells into potent immunostimulatory dendritic cells. J Exp Med 167: 700-705.

Higashi Y, Maruhashi M, Nelles L, Van de PT, Verschueren K, Miyoshi T, Yoshimoto A, Kondoh H, Huylebroeck D. 2002. Generation of the floxed allele of the SIP1 (Smadinteracting protein 1) gene for Cre-mediated conditional knockout in the mouse. Genesis 32: 82-84.

Hildner K, Edelson BT, Purtha WE, Diamond M, Matsushita H, Kohyama M, Calderon B, Schraml BU, Unanue ER, Diamond MS, et al. 2008. Batf3 deficiency reveals a critical role for $\mathrm{CD} 8 \alpha^{+}$dendritic cells in cytotoxic T cell immunity. Science 322: 1097-1100.

Holtl L, Rieser C, Papesh C, Ramoner R, Herold M, Klocker H, Radmayr C, Stenzl A, Bartsch G, Thurnher M. 1999 Cellular and humoral immune responses in patients with metastatic renal cell carcinoma after vaccination with antigen pulsed dendritic cells. J Urol 161: 777-782.

Hooper LV, Littman DR, Macpherson AJ. 2012. Interactions between the microbiota and the immune system. Science 336: $1268-1273$.

Inaba K, Inaba M, Romani N, Aya H, Deguchi M, Ikehara S, Muramatsu S, Steinman RM. 1992. Generation of large numbers of dendritic cells from mouse bone marrow cultures supplemented with granulocyte/macrophage colony-stimulating factor. J Exp Med 176: 1693-1702.

Inaba K, Inaba M, Deguchi M, Hagi K, Yasumizu R, Ikehara S, Muramatsu S, Steinman RM. 1993. Granulocytes, macrophages, and dendritic cells arise from a common major histocompatibility complex class II-negative progenitor in mouse bone marrow. Proc Natl Acad Sci 90: 30383042 .

Inaba K, Witmer-Pack M, Inaba M, Hathcock KS, Sakuta H, Azuma M, Yagita H, Okumura K, Linsley PS, Ikehara S, et al. 1994. The tissue distribution of the B7-2 costimulator in mice: Abundant expression on dendritic cells in situ and during maturation in vitro. J Exp Med 180: 18491860.

Jost PJ, Ruland J. 2007. Aberrant NF-кB signaling in lymphoma: Mechanisms, consequences, and therapeutic implications. Blood 109: 2700-2707.
Kabashima K, Banks TA, Ansel KM, Lu TT, Ware CF, Cyster JG. 2005. Intrinsic lymphotoxin- $\beta$ receptor requirement for homeostasis of lymphoid tissue dendritic cells. Immunity 22: 439-450.

Kashiwada M, Pham NL, Pewe LL, Harty JT, Rothman PB. 2011. NFIL3/E4BP4 is a key transcription factor for $\mathrm{CD} \alpha^{+}$dendritic cell development. Blood 117: 61936197.

Kee BL. 2009. E and ID proteins branch out. Nat Rev Immunol 9: 175-184.

Kobayashi T, Walsh PT, Walsh MC, Speirs KM, Chiffoleau E, King CG, Hancock WW, Caamano JH, Hunter CA, Scott P, et al. 2003. TRAF6 is a critical factor for dendritic cell maturation and development. Immunity 19: 353-363.

Komori T, Yagi H, Nomura S, Yamaguchi A, Sasaki K, Deguchi K, Shimizu Y, Bronson RT, Gao YH, Inada M, et al. 1997. Targeted disruption of Cbfa1 results in a complete lack of bone formation owing to maturational arrest of osteoblasts. Cell 89: 755-764.

Kretzer NM, Theisen DJ, Tussiwand R, Briseno CG, Grajales-Reyes GE, Wu X, Durai V, Albring J, Bagadia P, Murphy TL, et al. 2016. RAB43 facilitates cross-presentation of cell-associated antigens by $\mathrm{CD} 8 \alpha^{+}$dendritic cells. J Exp Med 213: 2871-2883.

Kumamoto Y, Linehan M, Weinstein JS, Laidlaw BJ, Craft JE, Iwasaki A. 2013. CD301b ${ }^{+}$dermal dendritic cells drive T helper 2 cell-mediated immunity. Immunity 39: 733-743.

Kusunoki T, Sugai M, Katakai T, Omatsu Y, Iyoda T, Inaba K, Nakahata T, Shimizu A, Yokota Y. 2003. $\mathrm{T}_{\mathrm{H}} 2$ dominance and defective development of a $\mathrm{CD} 8^{+}$dendritic cell subset in Id2-deficient mice. J Allergy Clin Immunol 111: 136142.

Lee MS, Kim YJ. 2007. Signaling pathways downstream of pattern-recognition receptors and their cross talk. Annu Rev Biochem 76: 447-480.

Lehtonen A, Veckman V, Nikula T, Lahesmaa R, Kinnunen L, Matikainen S, Julkunen I. 2005. Differential expression of IFN regulatory factor 4 gene in human monocyte-derived dendritic cells and macrophages. J Immunol 175: 6570-6579.

Leon B, Martínez del Hoyo G, Parrillas V, Vargas HH, Sanchez-Mateos P, Longo N, Lopez-Bravo M, Ardavin C. 2004. Dendritic cell differentiation potential of mouse monocytes: Monocytes represent immediate precursors of $\mathrm{CD}^{-}$and $\mathrm{CD} 8^{+}$splenic dendritic cells. Blood 103: 2668-2676.

Linehan JL, Dileepan T, Kashem SW, Kaplan DH, Cleary P, Jenkins MK. 2015. Generation of Th17 cells in response to intranasal infection requires TGF- $\beta 1$ from dendritic cells and IL-6 from CD301b ${ }^{+}$dendritic cells. Proc Natl Acad Sci 112: $12782-12787$.

Linette GP, Carreno BM. 2013. Dendritic cell-based vaccines: Shining the spotlight on signal 3. Oncoimmunology 2: $\mathrm{e} 26512$.

Liu K, Nussenzweig MC. 2010. Origin and development of dendritic cells. Immunol Rev 234: 45-54.

Liu CH, Fan YT, Dias A, Esper L, Corn RA, Bafica A, Machado FS, Aliberti J. 2006. Cutting edge: Dendritic cells are essential for in vivo IL-12 production and development of resistance against Toxoplasma gondii infection in mice 1. J Immunol 177: 31-35. 
D.A. Anderson et al.

Liu K, Waskow C, Liu X, Yao K, Hoh J, Nussenzweig M. 2007. Origin of dendritic cells in peripheral lymphoid organs of mice. Nat Immunol 8: 578-583.

Liu K, Victora GD, Schwickert TA, Guermonprez P, Meredith MM, Yao K, Chu FF, Randolph GJ, Rudensky AY, Nussenzweig M. 2009. In vivo analysis of dendritic cell development and homeostasis. Science 324: 392-397.

Longhi MP, Trumpfheller C, Idoyaga J, Caskey M, Matos I, Kluger C, Salazar AM, Colonna M, Steinman RM. 2009. Dendritic cells require a systemic type I interferon response to mature and induce $\mathrm{CD} 4^{+}$Th1 immunity with poly IC as adjuvant. J Exp Med 206: 1589-1602.

Manh TP, Alexandre Y, Baranek T, Crozat K, Dalod M. 2013. Plasmacytoid, conventional, and monocyte-derived dendritic cells undergo a profound and convergent genetic reprogramming during their maturation. Eur I Immunol 43: 1706-1715.

Mashayekhi M, Sandau MM, Dunay IR, Frickel EM, Khan A, Goldszmid RS, Sher A, Ploegh HL, Murphy TL, Sibley LD, et al. 2011. CD8a ${ }^{+}$dendritic cells are the critical source of interleukin-12 that controls acute infection by Toxoplasma gondii tachyzoites. Immunity 35: 249-259.

Massague J. 2004. $G_{1}$ cell-cycle control and cancer. Nature 432: 298-306.

Matsui T, Connolly JE, Michnevitz M, Chaussabel D, Yu CI, Glaser C, Tindle S, Pypaert M, Freitas H, Piqueras B, et al. 2009. CD2 distinguishes two subsets of human plasmacytoid dendritic cells with distinct phenotype and functions. J Immunol 182: 6815-6823.

Mayer CT, Ghorbani P, Nandan A, Dudek M, ArnoldSchrauf C, Hesse C, Berod L, Stuve P, Puttur F, Merad $\mathrm{M}$, et al. 2014. Selective and efficient generation of functional Batf3-dependent $\mathrm{CD}_{103^{+}}$dendritic cells from mouse bone marrow. Blood 124: 3081-3091.

Meredith MM, Liu K, Darrasse-Jeze G, Kamphorst AO, Schreiber HA, Guermonprez P, Idoyaga J, Cheong C, Yao KH, Niec RE, et al. 2012. Expression of the zinc finger transcription factor zDC (Zbtb46, Btbd4) defines the classical dendritic cell lineage. J Exp Med 209: 1153-1165.

Morelli AE, Thomson AW. 2007. Tolerogenic dendritic cells and the quest for transplant tolerance. Nat Rev Immunol 7: 610-621.

Murphy TL, Grajales-Reyes GE, Wu X, Tussiwand R, Briseno CG, Iwata A, Kretzer NM, Durai V, Murphy KM. 2016. Transcriptional control of dendritic cell development. Annu Rev Immunol 34: 93-119.

Naik SH, Proietto AI, Wilson NS, Dakic A, Schnorrer P, Fuchsberger M, Lahoud MH, O'Keeffe M, Shao QX, Chen WF, et al. 2005. Cutting edge: Generation of splenic $\mathrm{CD}^{+}$and $\mathrm{CD}^{-}$dendritic cell equivalents in Fms-like tyrosine kinase 3 ligand bone marrow cultures. J Immunol 174: 6592-6597.

Naik SH, Metcalf D, van Nieuwenhuijze A, Wicks I, Wu L, O'Keeffe M, Shortman K. 2006. Intrasplenic steady-state dendritic cell precursors that are distinct from monocytes. Nat Immunol 7: 663-671.

Naik SH, Sathe P, Park HY, Metcalf D, Proietto AI, Dakic A, Carotta S, O'Keeffe M, Bahlo M, Papenfuss A, et al. 2007. Development of plasmacytoid and conventional dendritic cell subtypes from single precursor cells derived in vitro and in vivo. Nat Immunol 8: 1217-1226.
Nair-Gupta P, Baccarini A, Tung N, Seyffer F, Florey O, Huang Y, Banerjee M, Overholtzer M, Roche PA, Tampe $\mathrm{R}$, et al. 2014. TLR signals induce phagosomal MHC-I delivery from the endosomal recycling compartment to allow cross-presentation. Cell 158: 506-521.

Nestle FO, Alijagic S, Gilliet M, Sun Y, Grabbe S, Dummer R, Burg G, Schadendorf D. 1998. Vaccination of melanoma patients with peptide- or tumor lysate-pulsed dendritic cells. Nat Med 4: 328-332.

Ohl L, Mohaupt M, Czeloth N, Hintzen G, Kiafard Z, Zwirner J, Blankenstein T, Henning G, Forster R. 2004. CCR7 governs skin dendritic cell migration under inflammatory and steady-state conditions. Immunity 21: 279288.

Ohtsuka H, Sakamoto A, Pan J, Inage S, Horigome S, Ichii H, Arima M, Hatano M, Okada S, Tokuhisa T. 2011. Bcl6 is required for the development of mouse $\mathrm{CD} 4^{+}$and $\mathrm{CD} 8 \alpha^{+}$ dendritic cells. J Immunol 186: 255-263.

Onai N, Kurabayashi K, Hosoi-Amaike M, Toyama-Sorimachi N, Matsushima K, Inaba K, Ohteki T. 2013. A clonogenic progenitor with prominent plasmacytoid dendritic cell developmental potential. Immunity 38: 943-957.

Otto F, Thornell AP, Crompton T, Denzel A, Gilmour KC, Rosewell IR, Stamp GW, Beddington RS, Mundlos M, Olsen BR, et al. 1997. Cbfal, a candidate gene for cleidocranial dysplasia syndrome, is essential for osteoblast differentiation and bone development. Cell 89: 765-771.

Ouaaz F, Arron J, Zheng Y, Choi Y, Beg AA. 2002. Dendritic cell development and survival require distinct NF- $\mathrm{\kappa B}$ subunits. Immunity 16: 257-270.

Palucka K, Banchereau J. 2013. Dendritic-cell-based therapeutic cancer vaccines. Immunity 39: 38-48.

Perry JS, Lio CW, Kau AL, Nutsch K, Yang Z, Gordon JI, Murphy KM, Hsieh CS. 2014. Distinct contributions of Aire and antigen-presenting-cell subsets to the generation of self-tolerance in the thymus. Immunity 41: 414-426.

Persson EK, Uronen-Hansson H, Semmrich M, Rivollier A, Hagerbrand K, Marsal J, Gudjonsson S, Hakansson U, Reizis B, Kotarsky K, et al. 2013. IRF4 transcription-factor-dependent $\mathrm{CD}_{103}{ }^{+} \mathrm{CD} 11 \mathrm{~b}^{+}$dendritic cells drive mucosal T helper 17 cell differentiation. Immunity 38: 958969.

Poulin LF, Salio M, Griessinger E, Anjos-Afonso F, Craciun L, Chen JL, Keller AM, Joffre O, Zelenay S, Nye E, et al. 2010. Characterization of human DNGR-1 ${ }^{+} \mathrm{BDCA}^{+}$ leukocytes as putative equivalents of mouse $\mathrm{CD} 8 \alpha^{+}$dendritic cells. J Exp Med 207: 1261-1271.

Romani N, Gruner S, Brang D, Kampgen E, Lenz A, Trockenbacher B, Konwalinka G, Fritsch O, Steinman RM, Schuler G. 1994. Proliferating dendritic cell progenitors in human blood. J Exp Med 180: 83-93.

Sallusto F, Lanzavecchia A. 1994. Efficient presentation of soluble antigen by cultured human dendritic cells is maintained by granulocyte/macrophage colony-stimulating factor plus interleukin 4 and downregulated by tumor necrosis factor $\alpha$. J Exp Med 179: 1109-1118.

Sallusto F, Schaerli P, Loetscher P, Schaniel C, Lenig D, Mackay CR, Qin S, Lanzavecchia A. 1998. Rapid and coordinated switch in chemokine receptor expression during dendritic cell maturation. Eur J Immunol 28: 2760-2769. 
Satpathy AT, Wumesh KC, Albring JC, Edelson BT, Kretzer NM, Bhattacharya D, Murphy TL, Murphy KM. 2012a. Zbtb46 expression distinguishes classical dendritic cells and their committed progenitors from other immune lineages. J Exp Med 209: 1135-1152.

Satpathy AT, Wu X, Albring JC, Murphy KM. 2012b. Re(de) fining the dendritic cell lineage. Nat Immunol 13: 11451154.

Satpathy AT, Briseno CG, Lee JS, Ng D, Manieri NA, Wumesh KC, Wu X, Thomas SR, Lee WL, Turkoz M, et al. 2013. Notch2-dependent classical dendritic cells orchestrate intestinal immunity to attaching-and-effacing bacterial pathogens. Nat Immunol 14: 937-948.

Savina A, Peres A, Cebrian I, Carmo N, Moita C, Hacohen N, Moita LF, Amigorena S. 2009. The small GTPase Rac2 controls phagosomal alkalinization and antigen crosspresentation selectively in $\mathrm{CD}^{+}$dendritic cells. Immunity 30: 544-555.

Sawai CM, Sisirak V, Ghosh HS, Hou EZ, Ceribelli M, Staudt LM, Reizis B. 2013. Transcription factor Runx2 controls the development and migration of plasmacytoid dendritic cells. J Exp Med 210: 2151-2159.

Scharton-Kersten T, Contursi C, Masumi A, Sher A, Ozato K. 1997. Interferon consensus sequence binding proteindeficient mice display impaired resistance to intracellular infection due to a primary defect in interleukin 12 p40 induction. J Exp Med 186: 1523-1534.

Schiavoni G, Mattei F, Sestili P, Borghi P, Venditti M, Morse HC III, Belardelli F, Gabriele L. 2002. ICSBP is essential for the development of mouse type I interferon-producing cells and for the generation and activation of $\mathrm{CD} 8 \alpha^{+}$ dendritic cells. J Exp Med 196: 1415-1425.

Schlitzer A, Loschko J, Mair K, Vogelmann R, Henkel L, Einwachter H, Schiemann M, Niess JH, Reindl W, Krug A. 2011. Identification of CCR9- murine plasmacytoid DC precursors with plasticity to differentiate into conventional DCs. Blood 117: 6562-6570.

Schlitzer A, McGovern N, Teo P, Zelante T, Atarashi K, Low D, Ho AW, See P, Shin A, Wasan PS, et al. 2013. IRF4 transcription factor-dependent $\mathrm{CD}_{11 \mathrm{~b}^{+}}$dendritic cells in human and mouse control mucosal IL-17 cytokine responses. Immunity 38: 970-983.

Schlitzer A, Sivakamasundari V, Chen J, Sumatoh HR, Schreuder J, Lum J, Malleret B, Zhang S, Larbi A, Zolezzi $\mathrm{F}$, et al. 2015. Identification of $\mathrm{CDC1}$ - and CDC2-committed DC progenitors reveals early lineage priming at the common DC progenitor stage in the bone marrow. Nat Immunol 16: 718-728.

Schoenberger SP, Toes RE, van der Voort EI, Offringa R, Melief CJ. 1998. T-cell help for cytotoxic T lymphocytes is mediated by CD40-CD40L interactions. Nature 393: 480-483.

Schuler G, Romani N, Steinman RM. 1985. A comparison of murine epidermal Langerhans cells with spleen dendritic cells. J Invest Dermatol 85: 99s-106s.

Scott CL, Soen B, Martens L, Skrypek N, Saelens W, Taminau J, Blancke G, Van Isterdael G, Huylebroeck D, Haigh J, et al. 2016. The transcription factor Zeb2 regulates development of conventional and plasmacytoid DCs by repressing Id2. J Exp Med 213: 897-911.

See P, Dutertre CA, Chen J, Gunther P, McGovern N, Irac SE, Gunawan M, Beyer M, Handler K, Duan K, et al. 2017.
Mapping the human DC lineage through the integration of high-dimensional techniques. Science doi: 10.1126/ science.aag3009.

Sepp M, Kannike K, Eesmaa A, Urb M, Timmusk T. 2011. Functional diversity of human basic helix-loop-helix transcription factor TCF4 isoforms generated by alternative $5^{\prime}$ exon usage and splicing. PLoS ONE 6: e22138.

Sichien D, Scott CL, Martens L, Vanderkerken M, Van Gassen S, Plantinga M, Joeris T, De Prijck S, Vanhoutte L, Vanheerswynghels M, et al. 2016. IRF8 transcription factor controls survival and function of terminally differentiated conventional and plasmacytoid dendritic cells, respectively. Immunity 45: 626-640.

Siegal FP, Kadowaki N, Shodell M, Fitzgerald-Bocarsly PA, Shah K, Ho S, Antonenko S, Liu YJ. 1999. The nature of the principal type 1 interferon-producing cells in human blood. Science 284: 1835-1837.

Smale ST. 2012. Dimer-specific regulatory mechanisms within the NF- $\mathrm{KB}$ family of transcription factors. Immunol Rev 246: 193-204.

Sonnenberg GF, Artis D. 2015. Innate lymphoid cells in the initiation, regulation and resolution of inflammation. Nat Med 21: 698-708.

Sozzani S, Allavena P, D’Amico G, Luini W, Bianchi G, Kataura M, Imai T, Yoshie O, Bonecchi R, Mantovani A. 1998. Differential regulation of chemokine receptors during dendritic cell maturation: A model for their trafficking properties. J Immunol 161: 1083-1086.

Steinman RM, Cohn ZA. 1973. Identification of a novel cell type in peripheral lymphoid organs of mice. I: Morphology, quantitation, tissue distribution. J Exp Med 137: $1142-1162$.

Steinman RM, Hawiger D, Nussenzweig MC. 2003. Tolerogenic dendritic cells. Annu Rev Immunol 21: 685-711.

Theisen D, Murphy K. 2017. The role of cDC1s in vivo: CD8 $\mathrm{T}$ cell priming through cross-presentation. F1000Res 6: 98.

Thurner B, Haendle I, Roder C, Dieckmann D, Keikavoussi P, Jonuleit H, Bender A, Maczek C, Schreiner D, von den DP, et al. 1999. Vaccination with mage-3A1 peptidepulsed mature, monocyte-derived dendritic cells expands specific cytotoxic $\mathrm{T}$ cells and induces regression of some metastases in advanced stage IV melanoma. J Exp Med 190: $1669-1678$.

Timmerman JM, Czerwinski DK, Davis TA, Hsu FJ, Benike C, Hao ZM, Taidi B, Rajapaksa R, Caspar CB, Okada CY, et al. 2002. Idiotype-pulsed dendritic cell vaccination for B-cell lymphoma: Clinical and immune responses in 35 patients. Blood 99: 1517-1526.

Tussiwand R, Lee WL, Murphy TL, Mashayekhi M, Wumesh KC, Albring JC, Satpathy AT, Rotondo JA, Edelson BT, Kretzer NM, et al. 2012. Compensatory dendritic cell development mediated by BATF-IRF interactions. $\mathrm{Na}$ ture 490: 502-507.

Tussiwand R, Everts B, Grajales-Reyes GE, Kretzer NM, Iwata A, Bagaitkar J, Wu X, Wong R, Anderson DA, Murphy TL, et al. 2015. Klf4 expression in conventional dendritic cells is required for $\mathrm{T}$ helper 2 cell responses. Immunity 42: 916-928.

Van de Putte T, Maruhashi M, Francis A, Nelles L, Kondoh H, Huylebroeck D, Higashi Y. 2003. Mice lacking ZFHX1B, the gene that codes for Smad-interacting pro- 
D.A. Anderson et al.

tein-1, reveal a role for multiple neural crest cell defects in the etiology of Hirschsprung disease-mental retardation syndrome. Am J Hum Genet 72: 465-470.

Vander LB, Khan AA, Hackney JA, Agrawal A, Lesch J, Zhou M, Lee WP, Park S, Xu M, DeVoss J, et al. 2014. Transcriptional programming of dendritic cells for enhanced MHC class II antigen presentation. Nat Immunol 15: 161-167.

Vandewalle C, Comijn J, De Craene B, Vermassen P, Bruyneel E, Andersen H, Tulchinsky E, Van Roy F, Berx G. 2005. SIP1/ZEB2 induces EMT by repressing genes of different epithelial cell-cell junctions. Nucleic Acids Res 33: 6566-6578.

Vandewalle C, Van Roy F, Berx G. 2009. The role of the ZEB family of transcription factors in development and disease. Cell Mol Life Sci 66: 773-787.

Van Dyken SJ, Nussbaum JC, Lee J, Molofsky AB, Liang HE, Pollack JL, Gate RE, Haliburton GE, Ye CJ, Marson A, et al. 2016. A tissue checkpoint regulates type 2 immunity. Nat Immunol 17: 1381-1387.

Villani AC, Satija R, Reynolds G, Sarkizova S, Shekhar K, Fletcher J, Griesbeck M, Butler A, Zheng S, Lazo S, et al. 2017. Single-cell RNA-seq reveals new types of human blood dendritic cells, monocytes, and progenitors. Science doi: 10.1126/science.aah4573.

von Moltke J, Ji M, Liang HE, Locksley RM. 2016. Tuft-cellderived IL-25 regulates an intestinal ILC2-epithelial response circuit. Nature 529: 221-225.

Waskow C, Liu K, Darrasse-Jeze G, Guermonprez P, Ginhoux F, Merad M, Shengelia T, Yao K, Nussenzweig M. 2008. The receptor tyrosine kinase Flt3 is required for dendritic cell development in peripheral lymphoid tissues. Nat Immunol 9: 676-683.

Watchmaker PB, Lahl K, Lee M, Baumjohann D, Morton J, Kim SJ, Zeng R, Dent A, Ansel KM, Diamond B, et al. 2014. Comparative transcriptional and functional profiling defines conserved programs of intestinal DC differentiation in humans and mice. Nat Immunol 15: 98-108.

Weih F, Carrasco D, Durham SK, Barton DS, Rizzo CA, Ryseck RP, Lira SA, Bravo R. 1995. Multiorgan inflammation and hematopoietic abnormalities in mice with a targeted disruption of RelB, a member of the NF- $\mathrm{K}$ B/Rel family. Cell 80: 331-340.

Weng Q, Chen Y, Wang H, Xu X, Yang B, He Q, Shou W, Chen Y, Higashi Y, van dB V, et al. 2012. Dual-mode modulation of Smad signaling by Smad-interacting protein Sip1 is required for myelination in the central nervous system. Neuron 73: 713-728.

Wilson NS, Young LJ, Kupresanin F, Naik SH, Vremec D, Heath WR, Akira S, Shortman K, Boyle J, Maraskovsky E, et al. 2008. Normal proportion and expression of maturation markers in migratory dendritic cells in the absence of germs or Toll-like receptor signaling. Immunol Cell Biol 86: 200-205.
Witmer-Pack MD, Olivier W, Valinsky J, Schuler G, Steinman RM. 1987. Granulocyte/macrophage colony-stimulating factor is essential for the viability and function of cultured murine epidermal Langerhans cells. J Exp Med 166: 1484-1498.

Wu L, D'Amico A, Winkel KW, Suter M, Lo D, Shortman K. 1998. RelB is essential for the development of myeloidrelated CD8 $\alpha$-dendritic cells but not of lymphoid-related CD8 $\alpha^{+}$dendritic cells. Immunity 9: 839-847.

Wu X, Briseno CG, Durai V, Albring JC, Haldar M, Bagadia P, Kim KW, Randolph GJ, Murphy TL, Murphy KM. 2016a. Mafb lineage tracing to distinguish macrophages from other immune lineages reveals dual identity of Langerhans cells. J Exp Med 213: 2553-2565.

Wu X, Briseno CG, Grajales-Reyes GE, Haldar M, Iwata A, Kretzer NM, Wumesh KC, Tussiwand R, Higashi Y, Murphy TL, et al. 2016b. Transcription factor Zeb2 regulates commitment to plasmacytoid dendritic cell and monocyte fate. Proc Natl Acad Sci 113: 14775-14780.

Wumesh KC, Satpathy AT, Rapaport AS, Briseno CG, Wu X, Albring JC, Russler-Germain EV, Kretzer NM, Durai V, Persaud SP, et al. 2014. L-Myc expression by dendritic cells is required for optimal T-cell priming. Nature 507: 243-247.

Yin X, Yu H, Jin X, Li J, Guo H, Shi Q, Yin Z, Xu Y, Wang X, Liu R, et al. 2017. Human blood $\mathrm{CD} 1 \mathrm{c}^{+}$dendritic cells encompass CD5high and CD5low subsets that differ significantly in phenotype, gene expression, and functions. $J$ Immunol 198: 1553-1564.

Yu H, Zhang P, Yin X, Yin Z, Shi Q, Cui Y, Liu G, Wang S, Piccaluga PP, Jiang T, Zhang L. 2015. Human $\mathrm{BDCA}^{+} \mathrm{CD} 123^{+} \mathrm{CD} 56^{+}$dendritic cells (DCs) related to blastic plasmacytoid dendritic cell neoplasm represent a unique myeloid DC subset. Protein Cell 6: 297-306.

Zhang J, Kalkum M, Yamamura S, Chait BT, Roeder RG. 2004. E protein silencing by the leukemogenic AML1ETO fusion protein. Science 305: 1286-1289.

Zhang H, Gregorio JD, Iwahori T, Zhang X, Choi O, Tolentino LL, Prestwood T, Carmi Y, Engleman EG. 2017a. A distinct subset of plasmacytoid dendritic cells induces activation and differentiation of B and T lymphocytes. Proc Natl Acad Sci 114: 1988-1993.

Zhang Q, Lenardo MJ, Baltimore D. 2017b. 30 Years of NF$\kappa \mathrm{B}$ : A blossoming of relevance to human pathobiology. Cell 168: 37-57.

Zheng Y, Valdez PA, Danilenko DM, Hu Y, Sa SM, Gong Q, Abbas AR, Modrusan Z, Ghilardi N, de Sauvage FJ, et al. 2008. Interleukin-22 mediates early host defense against attaching and effacing bacterial pathogens. Nat Med 14: 282-289.

Zou L, Zhou J, Zhang J, Li J, Liu N, Chai L, Li N, Liu T, Li L, Xie Z, et al. 2009. The GTPase Rab3b/3c-positive recycling vesicles are involved in cross-presentation in dendritic cells. Proc Natl Acad Sci 106: 15801-15806. 


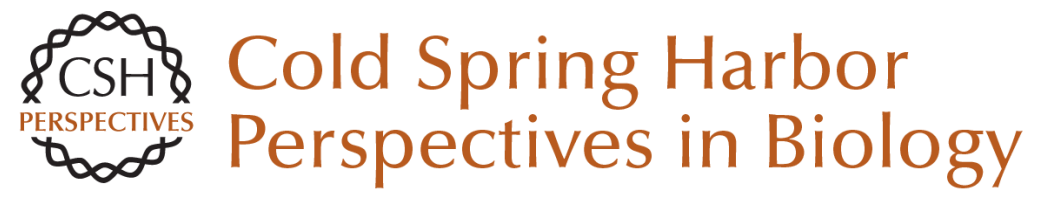

\section{Development, Diversity, and Function of Dendritic Cells in Mouse and Human}

David A. Anderson III, Kenneth M. Murphy and Carlos G. Briseño

Cold Spring Harb Perspect Biol 2018; doi: 10.1101/cshperspect.a028613 originally published online September 29, 2017

\section{Subject Collection Cytokines}

Interleukin (IL)-33 and the IL-1 Family of Cytokines

--Regulators of Inflammation and Tissue

Homeostasis

Ajithkumar Vasanthakumar and Axel Kallies

Targeting IL-10 Family Cytokines for the Treatment of Human Diseases

Xiaoting Wang, Kit Wong, Wenjun Ouyang, et al.

\section{Cytokine-Mediated Regulation of CD8 T-Cell} Responses During Acute and Chronic Viral Infection

Masao Hashimoto, Se Jin Im, Koichi Araki, et al.

Cytokines in Cancer Immunotherapy

Thomas A. Waldmann

The Tumor Necrosis Factor Family: Family Conventions and Private Idiosyncrasies David Wallach

The Interferon (IFN) Class of Cytokines and the IFN Regulatory Factor (IRF) Transcription Factor Family

Hideo Negishi, Tadatsugu Taniguchi and Hideyuki Yanai
Interferon $\gamma$ and Its Important Roles in Promoting and Inhibiting Spontaneous and Therapeutic Cancer Immunity

Elise Alspach, Danielle M. Lussier and Robert D. Schreiber

Inflammasome-Dependent Cytokines at the Crossroads of Health and Autoinflammatory Disease

Hanne Van Gorp, Nina Van Opdenbosch and Mohamed Lamkanfi

Innate Lymphoid Cells (ILCs): Cytokine Hubs

Regulating Immunity and Tissue Homeostasis Maho Nagasawa, Hergen Spits and Xavier Romero Ros

T Helper Cell Differentiation, Heterogeneity, and

Plasticity Jinfang Zhu

Development, Diversity, and Function of Dendritic

Cells in Mouse and Human

David A. Anderson III, Kenneth M. Murphy and Carlos G. Briseño

Cytokines and Long Noncoding RNAs Susan Carpenter and Katherine A. Fitzgerald

For additional articles in this collection, see http://cshperspectives.cshlp.org/cgi/collection/

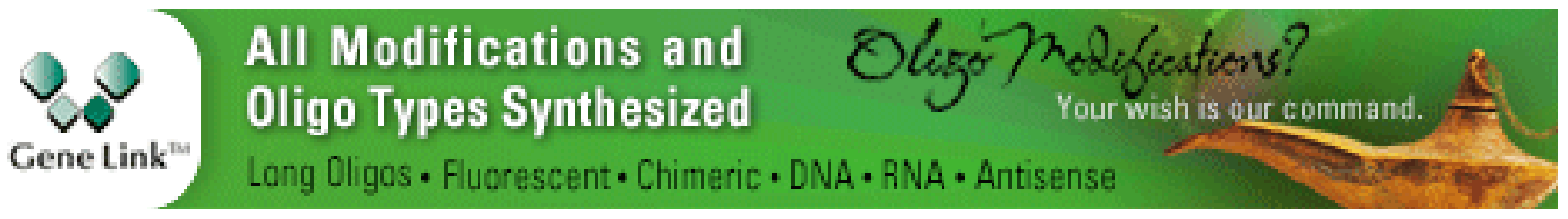


Role of the $\beta$ Common $(\beta \mathrm{c})$ Family of Cytokines in Health and Disease

Timothy R. Hercus, Winnie L. T. Kan, Sophie E. Broughton, et al.

Interleukin (IL)-12 and IL-23 and Their Conflicting Roles in Cancer Juming Yan, Mark J. Smyth and Michele W.L. Teng
Negative Regulation of Cytokine Signaling in Immunity

Akihiko Yoshimura, Minako Ito, Shunsuke Chikuma, et al.

Cancer Inflammation and Cytokines

Maria Rosaria Galdiero, Gianni Marone and Alberto Mantovani

For additional articles in this collection, see http://cshperspectives.cshlp.org/cgi/collection/

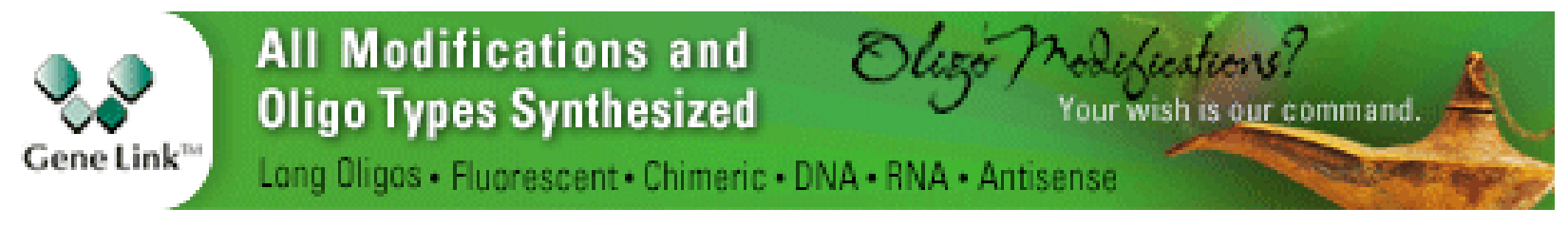

Copyright @ 2018 Cold Spring Harbor Laboratory Press; all rights reserved 